\title{
NOT JUST THE GIRL NEXT DOOR: FEMINIST EQUALITY STRATEGIES IN THE FACE OF THE "WOMAN OF LEGAL DISCOURSE"
}

\author{
By \\ Brynn Bourke \\ THESIS SUBMITTED IN PARTIAL FULFILLMENT OF \\ THE REQUIREMENTS FOR THE DEGREE OF \\ MASTER OF ARTS \\ In the Department of Law \\ (C) Brynn Bourke 2007 \\ CARLETON UNIVERSITY \\ December 2007
}

\begin{abstract}
All rights reserved. This work may not be reproduced in whole or in part, by photocopy or other means, without permission of the author.
\end{abstract}




$\begin{array}{ll}\begin{array}{l}\text { Library and } \\ \text { Archives Canada }\end{array} & \begin{array}{l}\text { Bibliothèque et } \\ \text { Archives Canada }\end{array} \\ \begin{array}{l}\text { Published Heritage } \\ \text { Branch }\end{array} & \begin{array}{l}\text { Direction du } \\ \text { Patrimoine de l'édition }\end{array} \\ \begin{array}{l}\text { 395 Wellington Street } \\ \text { Ottawa ON K1A 0N4 }\end{array} & \begin{array}{l}\text { 395, rue Wellington } \\ \text { Ottawa ON K1A ON4 }\end{array} \\ \text { Canada } & \begin{array}{l}\text { Canada } \\ \end{array}\end{array}$

Yourfile Votre référence

ISBN: 978-0-494-36806-0

Ourfile Notre référence

ISBN: 978-0-494-36806-0

NOTICE:

The author has granted a nonexclusive license allowing Library and Archives Canada to reproduce, publish, archive, preserve, conserve, communicate to the public by telecommunication or on the Internet, loan, distribute and sell theses worldwide, for commercial or noncommercial purposes, in microform, paper, electronic and/or any other formats.

The author retains copyright ownership and moral rights in this thesis. Neither the thesis nor substantial extracts from it may be printed or otherwise reproduced without the author's permission.
AVIS:

L'auteur a accordé une licence non exclusive permettant à la Bibliothèque et Archives Canada de reproduire, publier, archiver, sauvegarder, conserver, transmettre au public par télécommunication ou par l'Internet, prêter, distribuer et vendre des thèses partout dans le monde, à des fins commerciales ou autres, sur support microforme, papier, électronique et/ou autres formats.

L'auteur conserve la propriété du droit d'auteur et des droits moraux qui protège cette thèse. $\mathrm{Ni}$ la thèse ni des extraits substantiels de celle-ci ne doivent être imprimés ou autrement reproduits sans son autorisation.
In compliance with the Canadian

Privacy Act some supporting forms may have been removed from this thesis.

While these forms may be included in the document page count, their removal does not represent any loss of content from the thesis.
Conformément à la loi canadienne sur la protection de la vie privée, quelques formulaires secondaires ont été enlevés de cette thèse.

Bien que ces formulaires aient inclus dans la pagination, il n'y aura aucun contenu manquant.

\section{Canadä}




\section{Abstract}

Has equality strategizing reached an impasse? Some feminist legal theorists argue that we have taken equality as far as it can go and that it is now time to explore different models. But what is really holding equality back? Are its limitations inherent to the concept or only to its wielders? Has equality become a feminist orthodoxy that is operating as a constraint rather than a progressive force?

This thesis examines the role that feminist equality litigation strategies have played in reaffirming Carol Smart's "Woman of Legal Discourse," that is the essentialized woman constructed by law to stand in for all women and against whom all women are judged. This thesis draws upon Smart's theoretical concept of the "Woman of Legal Discourse" and attempts to tease out the characteristics of the mother of legal discourse that feminists have participated in creating.

In this thesis, I critically examine the Women's Legal Education and Action Fund and their intervention in Falkiner et al v. the Queen, in which they present to the courts a raceless, bodyless, young, heterosexual, "good" single mother as the mother worthy of equality, thus creating the mother of legal discourse. The cases of Winnipeg Child and Family Services (Northwest Area) v. G(DF) and Mossop v. Canada (Attorney General) are examined as examples of equality's potential to avoid such stereotyping and to present more complex women with intersecting identities. These cases offer models for resisting orthodoxy and reinvigorating equality as a legal strategy for all women. 


\section{Acknowledgements}

I would like to thank my husband Bradley, who did not hesitate to support me in going back to school. Writing this thesis has been a long and challenging process and I cannot thank him enough for being there throughout and believing in me.

I would like to thank my mother, father and brothers, for believing in me and always making me feel that I had the strength to achieve anything that I put my mind to. I know that I could not have taken this project on if not for growing up in such a loving and supportive household. Mom, I would like to thank you especially for the sacrifices that you have made, so that your children never had to sacrifice at all. And Dad, thank you for instilling in me a fierce sense of right and wrong. Whenever I get tired or discouraged, I rely on that sense of right, to motivate me to go out and try to make the world a better place.

I would also like to thank my aunt Leni and my best friend Jan. Leni for serving as a living example of what one person from Thunder Bay can do if they put their mind to it and Jan for consistently inspiring me with her wit, selflessness and intelligence.

I would like to thank my supervisor Diana Majury. I could not have asked for a better navigator along this journey. I thank you for your unfailing support and kind words throughout this process. It has been an honour and a privilege to work with you.

Finally, to the countless others who have been there along the way, I thank you. I never dreamed that I would or could go to graduate school or write a thesis and I certainly could not have done it if not for the gentle support and kindness of those teachers, family, and friends. I feel very privileged to have you all in my life. 


\section{Table of Contents}

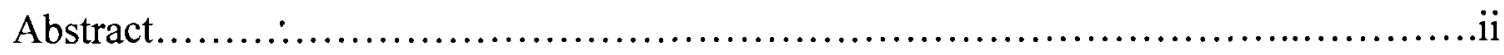

Chapter One

Essentialism is the " $E "$ in Equality ..............................................

Chapter Two

Charting a New Course: The Development and Impact of the Women's Legal

Education and Action Fund....................................................... 14

Chapter Three

Playing Telephone: Anatomy of a Stereotype....................................... 28

Chapter Four

Mothers, Lovers and Equality Flubbers: The Dangers of Over-Simplifying Single

Mothers........................................................................44

Chapter Five

Challenging Binaries: The Radical Potential of an Equality Framework................61

Chapter Six

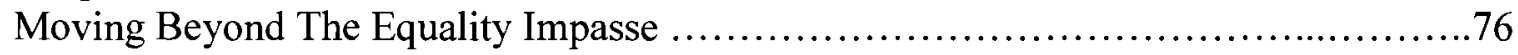

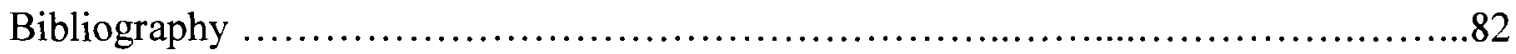

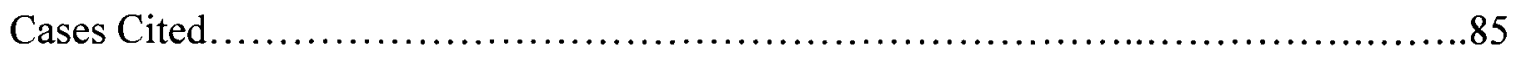




\section{Chapter One}

\section{Essentialism Is The "E" In Equality}

The legal field presents a unique challenge for feminist theorists. By using the law as our area of struggle, our engagement is confined by the law. Instead of controlling the terrain, we find ourselves controlled by the terrain, and although this does not mean that our interventions cannot challenge or push the envelope, it does mean that we cannot ignore the rules. For example, one of the limiting aspects of law is its reliance on categories and clear definitive boundary drawing. At least on an implicit level, law orders and requires essentialism. This relationship between essentialism and law can best be understood by examining the essentialized constructs that law produces through precedents and legal judgments. We can see this in the way likes are grouped together in boxes. The Charter ${ }^{1}$ categorizes protected groups beneath broad headings and then confirms rights and/or responsibilities based on perceived membership in a group. These essentializations run not just through Canada's constitution, but all through law: through definitions of marriage, family, employee, senior, etc. As feminist legal theorists we have struggled to challenge the categories into which women are expected to fit (or from which they are excluded) and at the same time we have tried to make connections with oppressed groups. However, in court we seek to present 'winnable' cases, which means that we necessarily rely upon those same contested categories in order to further the rights of our clients.

\footnotetext{
${ }^{1}$ Canadian Charter of Rights and Freedoms, Section 15, The Constitution Act, 1982.
} 
Equality as a framework confines us in much the same way. We can and do push the boundaries of equality analysis, but we are forced to face the reality that we cannot escape the limitations of equality that make up those boundaries. Equality has been criticized as obsolete on the one hand and utopian and unattainable on the other. But whatever else it is, equality is a key human rights/ Charter concept, and as such it is an important legal tool or strategy for feminists. Within feminist litigation strategies there has been a significant amount of debate around how to bring about equality, how to measure it, how to advocate for it, and how to prevent essentialization through it.

These equality questions are echoed in a more general debate that recently took place inside the pages of the Feminist Legal Studies between feminist legal scholars Anne Bottomley and Ngaire Naffine. Here the debate centered around feminist praxis on the question of how to engage in feminist legal theory. Bottomley linked the pattern of inquiry used by Naffine in her article, In Praise of Legal Feminism, ${ }^{2}$ to what Bottomley perceives as an overarching problem in feminist scholarship, which she refers to as "feminist orthodoxy." For Bottomley, such an orthodoxy arises out of the tendency in feminist scholarship to focus on the sameness of women's experience and the reproduction of the "woman as victim" model, ${ }^{4}$ to the exclusion of all other forms of presenting women. I was captured by how much this specific debate mimicked larger tensions taking place within feminist legal theory. Such tension can be felt in the feminist debates around language for example, raising such questions as whether we should write accessibly or use highly theoretical language, or whether we should write

\footnotetext{
Ngaire Naffine, "In Praise of Legal Feminism," Legal Studies, 22 (2002), 95-100. Anne Bottomley, "Shock To Thought: An Encounter (Of A Third Kind) With Legal Feminism," Feminist Legal Studies, 12 (2004).

4 This model will be explored more in chapter 3.
} 
generally or be more specific. We have seen such tensions arise over the presentation of women in our legal interventions: whether or not we should focus on similarities or focus on the differences between women, or whether we should deconstruct the category of woman or employ strategic labeling. There are also tensions that arise over our prospective audience: should we only address the feminist community or direct our comments to those not familiar with feminist theory; should we address our comments/critiques to men, women, the academy, the community, or some combination of all of these. These tensions have been borne out over and over again in feminist legal writing $^{5}$ as we have fought to find a balance between precision and accessibility, strength in numbers, and individuality/identity.

This thesis will ponder the questions: is it possible to use an equality approach that does not essentialize women's experiences, and to what extent can we break away from dangerous liberal paradigms that re-inscribe dominant power relations through the employment of essentializing categories?

\section{The Problem of Essentialism and Feminist Theory}

Put simply, essentialism is the universalized and abstract description of experiences. ${ }^{6}$ For feminists the problem of essentialism is the universalized description of women's experiences. Essentialism is thus a form of erasure. Through the process of categorization, many women are reduced to a series of pre-ordered characteristics, or even worse, are excluded completely. Historically, terms like "generalizations" or "stereotyping" have been used to denote when a category or person has been

5 For example, Catherine Mackinnon, Gayatri Spivak, bell hooks, etc.

6 Lise Gotell, "LEAF's Changing Approach to Charter Equality," in Radha Jhappan, ed., Women's Legal Strategies in Canada (Toronto: University of Toronto, 2002), 140. 
essentialized. The problem is the category itself and the need to categorize. If we reflect on this "need," the rationale is often related to simplicity and coherence. As Angela Harris has put it, "Essentialism is intellectually convenient, and to a certain extent cognitively ingrained. Essentialism also carries with it important emotional and political payoffs. Finally, essentialism often appears...as the only alternative to chaos." ${ }^{7}$ Yet, when we balance these rationales with the consequences of such essentializing, we often come up short. When we essentialize (especially in the court room), we trade complex identities for a simple identity. On some level, we are siding with the law in reproducing stereotypes that have been (and continue to be) held against marginalized peoples when they come before the courts.

We can trace contemporary feminist critiques of essentialism back to feminist social constructionism, perhaps most famously through the words of French feminist and philosopher Simone de Beauvoir when she stated, "One is not born, but rather becomes, a woman." Social constructionists "root their arguments in understandings of differences between and among women...they argue that there is a socially produced distinction between biological sex and gender." ${ }^{.9}$ We can make linkages from this first articulation of the construction of women's subject position to contemporary criticisms of what we now call essentialism. However, the term "essentialism" is more often, if not exclusively, used currently to critique engagements within the feminist community rather than to criticize external representations of women. Perhaps this shift reveals the success of de Beauvoir in that society has developed a much more rigorous understanding of

\footnotetext{
7 Angela Harris, "Race and Essentialism in Feminist Legal Theory" Stanford Law Review, 42, no.3(1990), 581-616.

${ }^{8}$ Simone De Beauvoir, The Second Sex, trans.H.M. Parshley, (London: Everyman, 1993) 281.

9 Wendy Kolmar, eds, et al "Intersections of Race, Class and Gender and Essentialism", Feminist Theory: A Reader. (California: Mayfield, 2000), 47.
} 
socialization and gender roles. The essentialization (or colloquially - "stereotyping") of various female positions is widely acknowledged as problematic. ${ }^{10}$

In many ways, the pressure simultaneously to breakdown essential categories and to attemp to win group-based victories in the courts has fueled a tug-of-war between essentialism and equality, taking feminist theorists to the brink of nothingness with postmodern explorations in an effort to liberate feminist theory from essentialism, or conversely, resorting to dangerously simplistic presentations of the problems facing women in order to grab the "win" in the courtroom. On one side, there are antiessentialists who call for the elimination of gender as a category because it is inherently and irredeemably essentialist. Judith Lorber calls for a feminist de-gendering movement that would do "away with binary gender divisions altogether." It is Lorber's contention that real equality can not exist while there is still a gender division in place. Her call for anti-essentialism is echoed in critical race theory by those who argue in favour of getting rid of race as an essentialist category. ${ }^{12}$ These extremes of anti-essentialism have been criticized for denying individuals the power and support of a group identity and for negating the reality of group-based discrimination and inequalities ${ }^{13}$.

Many feminist theorists have attempted to respond with their own versions of anti-essentialism, arguing that there are many different responses to the essentialist critique that do not require the elimination of the category "woman". For example, Iris Marion Young offers the concept of seriality. For Young, understanding gender as

10 Sara Salih, Judith Butler: Routledge Critical Thinkers (London: Routledge, 2002), 45.

11 Judith Lorber, "Using Gender to Undo Gender: A Feminist Degendering Movement," Feminist Theory 1 , no $1(2000), 79$.

12 Kwane Anthony Appiah, 'Racisms' in D.T. Goldberg, ed., Anatomy of Racism, (Minneapolis: University of Minnesota Press, 1990), 4.

13 Wendy Kolmar, eds, et al "Intersections of Race, Class and Gender and Essentialism", Feminist Theory: A Reader. (California: Mayfield, 2000), 47. 
seriality "provides a way of thinking about women as a social collective without requiring that all women have common attitudes or a common situation."14 Developed from Sartre's concept of seriality, gender as seriality attempts to balance the power of the collective with awareness of difference.

Alternatively, some anti-essentialist feminists have latched onto Gayatri Spivak's notion of "strategic essentialism." 15 They reject the notion of any natural essence of women as descriptively false and as denying and rendering invisible the diversity among and between women. ${ }^{16}$ Nevertheless, strategically they "act as if essentialism were true, so as to encourage a shared identification among women that enables them to engage in collective action." ${ }^{17}$ Essentialism is thus transformed from a belief about women's inherent nature into a strategy to address women's oppression.

The tension between anti-essentialism and giving individuals the power of a group through the recognition of group-based discrimination is captured by Martha Minow in a concept she describes as the "dilemma of difference". For Minow, the dilemma of difference arises because "treating people differently emphasizes their difference and stigmatizes or hinders them on that basis [while] treating people the same [can be] insensitive to their difference and likely stigmatize or hinder them on that basis." 18

14 Iris Marion Young, "Gender as Seriality: Thinking About Women as a Social Collectivity," Signs: Journal of Women in Culture and Society, 19 (1994), 723.

15 Sara Danius and Stefan Jonsson, "An Interview With Gayatri Chakravorty Spivak," Boundary 2, 20, no 2 (1993), 24.

16 Alison Stone, "Essentialism and Anti-Essentialism in Feminist Philosophy," Journal of Moral Philosophy, 1, no 2 (2004), 136.

17 Ibid., 143.

18 Martha Minow, Making All The Difference: Inclusion, Exclusion, And American Law (Ithaca: Cornell University Press, 1990), 20. 
Feminist legal theorists and litigators can relate to this dilemma in our own efforts to further equality without essentializing. As both equality and law tend to force us to essentialize categories, we often experience a double burden of essentialism. Women find themselves boxed into limited gendered categories -- mothers, widows, workers, pensioners -- where clear expectations are imposed and rewards and punishments serve to maintain the boundaries of the categories.

The dilemma of difference is exacerbated in legal contexts because of law's essentializing tendencies and "the dilemma persists when legal reasoning itself...treats those categories as natural and inevitable." ${ }^{19}$ Ultimately, Minow identifies this dilemma as a false one that arises out of the ways in which society organizes individuals. In this thesis, I am exploring the potential for feminist equality strategies to move beyond the false dilemma of essentialized equality.

\section{Equality and Essentialism}

Minow's point that the above tensions come out of the society that we live in is key to her analysis of the dilemma of difference. As feminist theorists attempt to carve out space for a diverse representation of human experiences, they find themselves constantly bumping up against a society organized by categories and boxes. I don't think that anti-essentialists are naïve or foolish in their attempts to organize our society differently and to eradicate differences of gender, race, etc; I agree in large part with many of their assertions. But like many feminist legal theorists, I am drawn to the winnable. Not just winnable in court hearings; but in overall moving us forward. Behind our test cases are real people, with very real needs. Under these conditions, many

$19 \quad$ Ibid., 22. 
feminist theorists have chosen to work within the "system". It is my belief that in this society we cannot ignore the boxes, but we can push them. This is where equality enters the arena, for I believe that equality can be "our" way of opening those boxes up rather than simply expanding them slightly.

It is perhaps at this point that I should "come out of the closet" as it were and "fess" up to being something of an equality lover. Having been raised as a "Charter baby", I find myself most unwilling to discard equality as a useful concept. As an equality "hanger-on", I want to give equality the benefit of the doubt by attributing some of its shortcomings to an unjust judge, or the historical climate in which essentialist actions were taken. Perhaps my attachment is a liability, preventing me from really critiquing some of the more systemic problems with equality analysis. However, I hope that it is an asset that will help me to find answers to some of the problems with equality that I will be raising throughout this thesis.

There is an old slogan: "Guns don't kill people, people kill people." Perhaps equality is something like this, in that "we" as feminist legal theorists, impose some of these flaws on equality in the way that we use it. Perhaps some of the things that we interpret as inherent to equality are not really inherent to the tool but indicative of the way we use that tool. However, at this point the gun analogy does begin to fail because at the end of the day, a gun is a gun and another famous slogan reminds us that you can't deliver peace or justice through its barrel.

In order to explore the equality/essentialism tension and how feminists have historically negotiated this terrain, this thesis will invoke Carol Smart's "Woman of Legal Discourse" as a theoretical tool that can help us to assess feminists' employment of 
essentialism in the court room. In The Woman of Legal Discourse, Smart identifies a dualism facing women in law. She makes a distinction between "the discursive production of a type of woman and the discursive construction of woman. ${ }^{20}$ By this she means that law perceives a "type" of woman who may be bad (i.e. the prostitute, the criminal, the single mother), while maintaining the category of "woman" as a whole as being in contradiction to man ${ }^{21}$. Smart gives the example of the single mother, who is both differentiated from other women while at the same time grouped in the prior category of woman, set-up in opposition to men. ${ }^{22}$ This single mother is both set apart from other women and through her very existence in the category of women, set up as a counter example to what the good woman/mother should look like. ${ }^{23}$ She is both separate from and a model for women. It is Smart's contention that through this set of binaries woman comes into being in law.

Smart's construct provides me with a theoretical reference point from which to assess how much feminists active in the courts essentialize the various categories that women can fall into, by exploring to what extent "we" reproduce this "Woman of Legal Discourse" in our court interventions. For example, if we take Smart's construct of the prostitute, there are a host of characteristics that the law assumes prostitutes share, namely, promiscuity, addiction, alcoholism, sexually transmitted diseases, unemployment, poor education, and racialization. These characterizations are loaded with moral valuations that give rise to another set of negative assumptions, for example, that prostitutes are lazy, unfit mothers, and in general a drain on society. The laws

20 Carol Smart, "The Woman of Legal Discourse" in Carol Smart, Law, Crime and Sexuality: Essays in Feminism (London: Sage, 1995), 193.

Ibid., 193.

Ibid., 195.

Ibid., 193. 
surrounding prostitution reflect these negative assumptions by criminalizing prostitution, putting more emphasis on targeting prostitutes than johns, and denying prostitutes access to social services like workers' compensation, employment insurance, etc. By recognizing that "the prostitute" is a manifestation of a "Woman of Legal Discourse," we are able to unpack her construction, identify what features are essentialised, and problematize our own role in negatively re-inscribing her. Taking this example further, once we identify some of the myths that construct "the prostitute," we can look to see if some of these same myths are present or at least remain unchallenged in our representations of prostitution.

In order to unpack these "women," we must critically examine the narratives that are being used in their creation/re-inscription. Loreen Snider's work on feminist knowledge claims and the way(s) in which such claims are transmitted and received by society is an important component in understanding our role in contributing to the construction of these "Women of Legal Discourse." Snider's examination of narratives and the transformative potential of our interventions provides a nuanced analysis of the relationship between our legal interventions and their outcome. This understanding of the role and power of narrative within law is useful in grounding the problem of the "Woman of Legal Discourse." Together, Smart and Snider provide the theoretical tools that allow me to understand our relationship with essentialism and our role in reinscribing an essentialized "woman" through the employment of essentializing categories.

I will be using Smart's construct of the "Woman of Legal Discourse" to concentrate on the narratives used in legal equality strategies that can lead to the kind of 
good/bad binaries that the "Women of Legal Discourse" relies upon, in order to critique and understand the relationship between equality and essentialism.

\section{Agents of Change}

The last twenty years have been monumental for feminist activism in the Supreme Court of Canada. To borrow a phrase from an unlikely source, Morton claims there has been a "Charter Revolution." ${ }^{24}$ At the forefront of this "revolution" has been LEAF, the Women's Legal Education and Action Fund. Through case interventions, conferences, and articles, LEAF has made equality its business. LEAF has been at the forefront of securing spousal recognition for gay and lesbian couples $^{25}$, winning the right for parental leave ${ }^{26}$, and playing an instrumental role in securing spousal support for thousands of women. ${ }^{27}$ They fought for improvements in work place standards, ${ }^{28}$ and worked to secure a definition of consent in sexual assault ${ }^{29}$ and secure changes to rape laws, ${ }^{30}$ protecting victims of assault from having their personal histories held against them in a courtroom. As the most frequent intervener in court cases, ${ }^{31}$ LEAF is the most important feminist voice in the Canadian courtroom. This has placed the burden of representation

24 F. L. Morton and Rainer Knopff, The Charter Revolution and The Court Party, (Peterborough: Broadview Press, 2000).

25 M. v. H., [1999] 2 S.C.R. 3.

26 Schatcher v. Canada [1992] 2 S.C.R. 679.

27 LEAF was an intervener in Moge v. Moge, [1992] 3 S.C.R. 813. This case was the catalyst that led to a fundamental change in spousal support after the breakdown of a marriage. LEAF's argument that work taken on in the home facilitated the paid work done outside of the home helped to secure a more equitable distribution of family asserts.

${ }_{28}$ British Columbia (Public Service Employee Relations Commission) v. British Columbia Government Service Employees' Union [1999] 3 S.C.R. 3, 1999 SCC 48

29 R. v. Ewanchuk, [1999] 1 S.C.R. 330

${ }_{30}$ R. v. Darrach, [2000] 2 S.C.R. 443, 2000 SCC 46

31 F.L. Morton and Allen, Avril "Feminists and the Courts: Measuring Success in Interest Group Litigation in Canada," Canadian Journal of Political Science, 34 (2001), 57. 
on LEAF in that, as the most common voice for women's rights in the courts, it can often be taken as "the" voice of Canadian women in the courtroom.

This thesis first explores the role that LEAF has played in the courts as the major proponent and articulator of women's Charter equality claims. Chapter Two of this thesis examines the origins and development of LEAF, how it came to exist and the current environment in which it operates. This background provides me with a basis from which to evaluate more critical questions relating to LEAF's chosen framework (equality), their means of presenting women, and the way in which their knowledge claims are perceived. Chapter Two also looks at the contemporary critiques of LEAF and examines some of the challenges that LEAF is facing.

Chapter Three uses the Bottomley/Naffine debate to unpack broader questions around the strategic use of equality. I adapt Bottomley's accusation of a feminist orthodoxy in order to examine whether LEAF has fallen into an orthodoxy that accepts and reaffirms the "Woman of Legal Discourse." This chapter also brings in Lorreen Snider's knowledge-power-change nexus to help me identify if and how Smart's "Woman of Legal Discourse" has been created and reproduced by LEAF and examines LEAF's power as a narrative builder.

These theoretical tools are pulled together in a case study in Chapter Four. LEAF's intervention in Falkiner vs. Ontario ${ }^{32}$ is examined, with particular attention to LEAF's role in affirming a single mother "Woman of Legal Discourse." Through this case study, we are able to contextualize the problem with essentializing categories and to think through some of the ripple effects of presenting an uncomplicated essentialized woman to the courts.

32 Falkiner v. Ontario (Ministry of Community and Social Services, [2002], 59 O.R. (3d) 481 
Chapter Five operates as a foil to Chapter Four. LEAF's factum in the Winnipeg Child and Family Services $v$. $G(D F)$ is presented as an example of how we can challenge our own role in reinforcing a "Woman of Legal Discourse" by presenting a lessessentialized woman to the courts. The case of Canada v. Mossop is also examined as a potential alternative form of engagement that might help us to theorize about how we use equality and organize our interventions. Chapter Six offers a possible way forward for LEAF in equality strategizing. 


\section{Chapter Two}

\section{Charting A New Course: The Development and Impact of the Women's Legal Education and Action Fund}

The climate in which LEAF was born plays a tremendous role in explaining its actions today. While the development of a feminist legal organization that roots itself in an equality approach is in every way tied to the social expectations and opportunities afforded to women in the latter half of the $20^{\text {th }}$ century and to the political and social context, the connection between Canadian feminism and equality reaches much further into the past than the 1960s. Equality has long been a central tenet of liberalism. Suffragettes used equality as part of their rationale for the women's right to vote. Since liberalism was the prevailing philosophy, it was this liberal tool and its language of equality that the group of five and others held onto and used in front of the Privy Council to gain legal personhood. ${ }^{33}$ Liberalism continues to prevail and equality continues to underpin and frame the legal activism of contemporary feminists.

A product of their time as well, LEAF's own history and roots are deeply connected to the status of equality and equality debates. Though the Women's Legal Education and Action Fund was incorporated in $1985,{ }^{34}$ the real history that informs its creation starts much earlier in the 1970s when the Royal Commission on the Status of Women released a report on the status of women in Canada. In the report, 167

33 Veronica Strong-Boag, "Ever a Crusader: Nellie McClung" in Veronica Strong-Boag and Anita Clair Fellman, eds., Rethinking Canada: The Promise of Women's History, $3^{\text {rd }}$ ed., (Don Mills: Oxford University Press, 1997) 275.

34 Women's Legal Education and Action Fund, "About LEAF Foundation," Accessed July 2006, $<$ http://www.leaf.ca/foundation.html $>$ 
recommendations were made detailing changes necessary for improving the position of women in Canadian society. These included recommendations for greater access to day care and birth control and reforms to family law. In an effort to ensure that the recommendations put forward by the Commission were followed through, several of the women's groups who had initially pushed for the Commission to be struck re-formed to create the National Ad-hoc Committee on the Status of Women. ${ }^{35}$

When the federal government announced in 1980 that it intended to add a Charter of Rights and Freedoms to the new Constitution, the National Action Committee on the Status of Women (the Ad-Hoc was switched to "action" because the federal government refused to fund Ad-Hoc committees) instigated a national debate involving many women's groups to discuss how this new document could be used as a tool for improving women's lives. ${ }^{36}$

A key element of this debate was raised by feminists interested in enhancing the equality language that already existed in the Bill of Rights. ${ }^{37}$ Their goal was to protect women from unequal treatment before and under the law. Specifically, women were outraged by the Lavell $^{38}$ and Bliss ${ }^{39}$ cases in which the "rule of law" had been used to justify overt and egregiously unequal treatment of women. As both Lavell and Bliss were decided under the Canadian Bill of Rights, it was understood that stronger equality language was needed, language that would prevent courts from rationalizing unequal treatment through deference to the legislature.

35 National Action Committee on the Status of Women, "Herstory," Accessed August 2006, $<$ http://www.nac-cca.ca/about/his_e.ht $>$

Ibid.

Canadian Bill of Rights, August 10, 1960. Part 1, Section 1. Attorney General of Canada v. Lavell; Isaac v. Bedard, [1974] S.C.R. 1349.

Bliss v. Canada (Attorney General), [1979] 1 S.C.R. 183. 
I am interested in this time period both because of the type of cases that had enraged women enough to give rise to a sex discrimination complaint under the Canadian Bill of Rights and because of the reasons they were enraged. Feminists saw a very clear breach of equality principles in both Lavell and Bliss. Jeanette Lavell was a First Nations woman who challenged Section 12(1b) of the Indian Act, which removed her status as an Indian because she had married a non-Indian man (a rule which did not apply to Indian men who married non-Indian women). ${ }^{40}$ The Supreme Court found that such differentiation between men and women was not discriminatory; ${ }^{41}$ the decisive point was that all women were treated the same, in effect were given "equality before the law" and that was all that was guaranteed by the Bill of Rights. What was missing was "equality under the law.",42

Stella Bliss challenged the federal unemployment insurance program that required "pregnant women to have worked a longer qualifying period than other unemployed workers before qualifying for benefits." ${ }^{43}$ The Supreme Court of Canada ruled that "discrimination on the basis of pregnancy was not discrimination on the basis of sex because the distinction was not between men and women, but between pregnant and nonpregnant persons." ${ }^{44}$ Justice Pratte, speaking for the majority, reasoned that pregnancy was a voluntary choice and a gift, and that since the Canadian government very reasonably did not want new mothers to work a special benefit package was appropriate

Attorney General of Canada v. Lavell; Isaac v. Bédard, [1974] S.C.R. 1349.

41 Gwen Brodsky and Shelagh Day, Canadian Charter Equality Rights For Women: One Step Forward or Two Steps Back? (Ottawa: Canadian Advisory Council on the Status of Women, 1989), 14.

42 The Women's Legal Education and Action Fund, "LEAF Beginnings," Accessed January 2007, $<$ http://www.leaf.ca/about-begin.html $>$

43 Bliss v. Canada (Attorney General) [1979] 1 S.C.R. 183.

44 The Women's Legal Education and Action Fund, "LEAF Beginnings," Accessed January 2007, $<$ http://www.leaf.ca/about-begin.html $>$ 
for them, even if said package denied new mothers benefits to which they were otherwise entitled. $^{45}$

The outrage that these women were denied the same treatment that their male counterparts were accorded led feminists to make stronger equality language their focus in their Charter lobby. In anticipation of the sweeping effects that a change to equality provisions under the Charter would bring, the government postponed for three years the coming into force of the Charter equality provisions. During this three year moratorium, feminist groups actively organized to ready themselves for the Charter's implementation. Many feminist Charter advocates realized that an organized body was needed to spearhead a feminist voice within the courts. At a 1982 conference sponsored by the Status of Women entitled "Women and the Constitution," future co-founder of LEAF, Beth Atcheson, declared in a speech to the assembly that Canada needed a Canadian women's litigation fund. ${ }^{46}$ Delegates at the meeting jumped on the idea and the Canadian Advisory Council on the Status of Women financed a study of American legal defense funds and how such a fund might be created in Canada; the study was called the Woman and Legal Action study. ${ }^{47}$

Published in 1984, the study served as the outline for the creation and organization of LEAF. The study examined American models of test case litigation funds and how such funds could be created and structured in Canada. The study provided recommendations for the creation of a women's Charter equality advocacy organization. The study called for a unified women's law fund to be created in order to achieve the

\footnotetext{
45 Sherene Razack, Canadian Feminism and the Law: The Women's Legal Education and Action Fund and the Pursuit of Equality (Toronto: Second Story Press, Feminist Publishers, 1991), 31.

46 Ibid., 36.

47 Ibid., 36.
} 
most control over the development of equality law. This fund would take the same approach to litigation development as had been successful for organizations in the United States. The focus would be to educate the public on inequality and to change legislation and advocate for the creation of new laws. ${ }^{48}$ As a result of the study LEAF was incorporated on April 17, 1985 as a non-profit society, with equality as its core mandate.

Support for equality made perfect sense in the context of a post-Lavell and Bliss environment, where women had been denied the most basic of rights. However, in hindsight, we might be a bit more critical, in that the type of equality being advocated at that time is now understood as "formal" equality, a limited notion of equality that focuses on the same treatment for everyone. Formal equality sets the male standard as the goal to which women should aspire and puts women in the position of arguing for the same treatment as men. Essentializing women's experience and constructing a "generic female identity that denies significant differences between women" ${ }^{\text {"49 }}$ became a critical step in grounding the male/female comparison required by formal equality. In their formative years, LEAF's approach to equality focused heavily on this formal equality model which "prescribes the equal (or same) treatment of all individuals regardless of existing circumstances." ${ }^{, 50}$ Though not surprising for the times, considering that women as a group had many shared barriers to formal equality, this framework left many women behind. It located gender as the nexus that connected all members of the group, thus placing gendered concerns and identities as separate from and above racial, cultural,

48 Canadian Advisory Council on the Status of Women, Women and Legal Action: Precedents, Resources and Strategies for the Future (Ottawa: Status of Women, 1984), 167-170.

49 Radha Jhappan, "The Equality Pit or the Rehabilitation of Justice", in Radha Jhappan, ed., Women's Legal Strategies in Canada, (Toronto: University of Toronto, 2002), 177.

50 Melina Buckley, Transforming Women's Futures: A Guide to Equality Rights Theory and Action, (Vancouver: West Coast Women's Legal Education and Action Fund, 2001), 42. 
spiritual, physical, economic, disability, and sexuality issues of equal (or greater) concern to many women.

\section{LEAF and Equality}

Responding to the limitations of formal equality, LEAF has since made efforts to put forward a much more nuanced approach to equality, known as substantive equality. Substantive equality differs from the classical equality approach reflected in formal equality and instead endeavors to secure an equality of outcome in each case. The approach demands "the redress of existing inequality and the institution of genuine, real, effective equality in the social, political and economic conditions of different groups in society. Substantive equality requires a focus on systemic and group-based inequalities." ${ }^{.51}$ The hope is that multiple barriers and women's intersecting identities can be addressed using this method.

The first major public break with a "formal" equality approach took place in LEAF's intervention in Andrews v. Law Society of British Columbia in 1989, the first s.15 Charter equality case to go before the Supreme Court of Canada. In Andrews, a British subject, Mark David Andrews, challenged his disqualification from the British Columbia Bar Association on the grounds that he was not a Canadian citizen by arguing that such a requirement infringed his section 15 equality rights as granted by the Charter. ${ }^{52}$ Although the Supreme Court of British Columbia denied Andrews' claim, it was overturned at the British Columbia Court of Appeal and the Supreme Court of Canada.

Ibid., 42.

52 Andrews v. Law Society of British Columbia, [1989] 1 SCR 143 
It was in Andrews that LEAF first articulated the "contextualized approach to Charter sexual equality," or the CASE approach as it was later coined by Lise Gotell. Using the CASE approach, LEAF argued that women's constitutional equality claims could not be adequately addressed by treating likes alike, but rather that they must be examined from the standpoint of women's experiences. This approach attempts to frame "sexual equality claims within the context of gendered relations of power and insists that adjudication be based on an evaluation of the impact for women's subordination." ${ }^{, 53}$ The Supreme Court of Canada in Andrews explicitly rejected the formal equality model and adopted substantive equality as the meaning of equality under Canada's Charter.

In Andrews, LEAF opened an important door. With that door open, they spent the next fifteen years attempting to grapple with what a substantive equality approach would really look like theoretically and in terms of their own case process. As a significant step in the process of adopting a substantive equality approach, LEAF constructed an Outreach and Diversification Plan, which called for consultations with traditionally marginalized women as well as concrete steps to enable women from different areas, experiences, and communities to formally participate in LEAF. In addition, the plan committed them to creating permanent liaison positions that would network with diverse feminist organizations and to establishing an employment equity plan that would ensure progressive hiring within the organization. ${ }^{54}$

\footnotetext{
53 Lise Gotell, "LEAF's Changing Approach to Charter Equality," in Radha Jhappan, ed., Women's Legal Strategies in Canada, (Toronto: University of Toronto, 2002), 138.

$54 \quad$ lbid., 146-147.
} 


\section{LEAF's Critics and Supporters}

From the right, authors like Morton have criticized LEAF as a special interest group, ${ }^{55}$ and from the left theorists like Gotell and Jhappan have critiqued LEAF as an organization trapped in and by liberalism. An extensive literature review reveals that almost all commentators, on the right and on the left, have identified LEAF as a major if not "the" major feminist force in the courtroom.

In The Charter Revolution and the Court Party, Morton and Knopff are critical of the impact that (as they describe it) the "Court Party" (partisan non-governmental organizations) has had on the "judicial activism" of the courts. ${ }^{56}$ They attribute the courts' activism to a "moral oversensitivity" that comes from the "temptation to inflate objectively minor disagreements into major conflicts. ${ }^{, 57}$ For Morton and Knopff, organizations like LEAF have dominated this (mis)direction of the courts. They argue that these "special interest groups" circumvent the democratic authority of the legislature by taking their concerns to the courts instead of having them debated in the House. ${ }^{58}$ LEAF is interpreted as being very successful in terms of their ability to bend the courts to their will, even though this "success" is seen negatively by the authors. Clearly infused with a right-wing agenda, Morton's book provides a unique window into the perception of LEAF from this political perspective. For observers on the right, LEAF is viewed as overly powerful - so powerful that they are seen as setting the agenda for the courts. This theme is carried on in all of Morton's work on the subject.

55 F. L. Morton and Rainer Knopff, The Charter Revolution and The Court Party, (Peterborough: Broadview Press, 2000).

56 Ibid., 25

57 Ibid., 157.

58 Ibid. 
These attacks from the right not only serve as a response to the work that LEAF is doing, but also have an impact on the public perception of LEAF and ultimately on public and government support for LEAF. In the latest round of funding cuts made by the Conservative government in 2006, LEAF saw drastic cuts in funding to coalition partners funded by the Status of Women, as well as the elimination of the Court Challenges program that had funded much of LEAF's work.

From the left, LEAF has been criticized for its reliance on the equality framework. One of these left-wing critics is Lise Gotell. She criticizes the CASE approach for being similar to standpoint feminism. A branch of Marxist feminism coined by Nancy Hartsock, standpoint feminism attempts to provide a methodological grounding that will justify feminist truth claims on the grounds that women occupy a unique position in society. ${ }^{59}$ Gotell argues that CASE and standpoint feminism share two disturbing traits. First, both approaches rely on an essential female experience in order to construct the women's voice that the courts are meant to hear. For Gotell, the creation of the female voice is essentialist because the diversity and varied experiences of women before the courts is conflated into one voice. Gotell indicates that this essentialism is inherent to a CASE framework. Second, both approaches appeal to an assumption that truth can supersede power: "The CASE approach invited the judiciary to "come down among women' because this is a site of powerlessness and powerlessness is 'truthful' ., "60 Here Gotell is critical of LEAF for being naïve in assuming that the courts will accept

59 Susan Hekman, "Truth and Method: Feminist Standpoint Theory Revisited," Signs: Journal of Women in Culture and Society, 22, no.21, (1997), 341.

60 Lise Gotell, "LEAF's Changing Approach to Charter Equality," in Radha Jhappan, Women's Legal Strategies in Canada, (Toronto: University of Toronto, 2002), 139-140. 
women's voice as truth and that simply because a woman claims to experience discrimination the court will accept that she has been discriminated against.

In "The Equality Pit or the Rehabilitation of Justice", Jhappan argues that structuring demands for social change in terms of equality/inequality limits our engagement by conceding that solutions can only be found in a liberal rights framework. ${ }^{61}$ As a comparative tool, equality is incapable of reaching for solutions to inequality outside of the dominant paradigm, because the comparator is necessarily a liberal figure with more power than the claimant: usually the liberal man. Jhappan exposes the problem of "operationalizing" equality in that it forces feminists into the comparison debate framed as the same treatment or different treatment by forcing the statement: (A) should/ would be equal to (B) if she had access to (C). This formula demands an essentialized subject (A) to be compared to an essentialized subject (B) leading to treatment (C) (either the same treatment or different treatment, but always measured in comparison to (B)) as the solution to equality. Thus, the combination of A and $\mathrm{C}$ puts $\mathrm{A}$ in the same position as liberal power holder $\mathrm{B}(\mathrm{A}+\mathrm{C}=\mathrm{B})$.

\section{The Limitations of Equality}

Both Gotell and Jhappan's critiques of equality are useful in that they force the reader to confront the limitations of equality analysis and to contemplate alternatives. While Gotell does not go down this road, Jhappan does give us an alternative framework of justice. Jhappan rejects equality approaches in favour of a theory of justice because she feels that justice can better allow for a retreat from essentialism by not operating through

61 Radha Jhappan, "The Equality Pit or the Rehabilitation of Justice," in Radha Jhappan, ed., Women's Legal Strategies in Canada, (Toronto: University of Toronto, 2002), 177. 
comparative principals. However, upon examination this alternative appears to share the same problems as equality. Justice is also an inherently liberal concept rife with the individualistic trappings of liberalism condemned by Jhappan in relation to equality. Jhappan leaves unanswered the question of how this justice alternative would be articulated and assessed without encountering the problems of comparison and essentialism that she and Gotell critique in equality. It is not that these critiques are illegitimate, but rather that the critiques may be more fundamental to liberalism more generally and require a more strategic than analytical response.

Ironically, the most coherent and thorough critique of equality comes from LEAF itself in its guide Transforming Women's Futures: A Guide to Equality Rights Theory and Action, produced by West Coast LEAF and edited by Melina Buckley. Although most of the analysis in the section on "Legal Equality: Problems and Concerns" is derived from the work of Diana Majury and Carissma Mathen, the guide is a record of the debates and discussions that took place at LEAF's Transforming Women's Future: Equality Rights in the New Century conference held from November 4-7 in 1999 in Vancouver. Thus, the guide provides a timely analysis of the ideas/concepts and strategies that LEAF members were grappling with at the turn of this century.

The guide identifies eight key limitations of equality: 1) equality is by definition comparative; 2) equality essentializes categories; 3 ) equality is about asserting a negative, not a positive right; 4) "gender" is both over and under inclusive; 5) equality is gender neutral: 6) formal equality continues to inform equality analysis; 7) an equality analysis is either simplistic or unhelpful in pointing to a remedy; and 8) equality is an abstraction. ${ }^{62}$

62 Melina Buckley, Transforming Women's Futures: A Guide to Equality Rights Theory and Action, (Vancouver: West Coast Women's Legal Education and Action Fund, 2001), 60-61. 
For many of these points, the crucial downfall of equality seems to circle back to essentialism. To compare groups we must essentialize them. Gender is essentialized (along with race, disability, sexual orientation, for example) and formal equality is problematic at least in part because it essentializes. The two - equality and essentialism seem inextricably linked. This does not necessarily mean that feminist legal theorists should throw up their hands and sink into a twenty year quest for an alternative. A question of degree can be posed. To what extent is equality inherently essentialist? Are there ways that we can mitigate essentialism? When might it be appropriate to embrace some forms of essentialism (perhaps Spivak's notion of strategic essentialism) and when is such an approach harmful? Can we simultaneously challenge essentialism and rely on it?

LEAF can be identified as a leader in terms of the ways in which they have attempted to stretch equality to its very boundaries with their substantive equality "results oriented" approach. This method, which removes equality from a sameness analysis to a contextualized approach, attempts to make equality fluid. Although it may still be comparative, the analysis shifts the basics for comparison from equality of opportunity to comparing equality of outcome. This method employed by LEAF allows for different roads to responding to discrimination to be taken. There may still be an essentialized end point and most likely an essentialized subject position, but the essentialized assumption of common opportunity has been removed. This shift in thinking affects not only the starting reference point, but also the presentation of the starting subject(s). To harken back to the formula $\mathrm{A}+\mathrm{C}=\mathrm{B}$ used when explaining Jhappan's critique, the results oriented approach allows for a less essentialized (A) and (B) by virtue of problematizing 
the subject positions of $(\mathrm{A})$ and $(\mathrm{B})$ when it breaks away from the assumption of "common opportunity" that if invoked would narrow and constrict both A and B. The result-oriented approach thus offers us a more robust, less essentialist mode of equality analysis.

However, as cases like Falkiner v. the Queen demonstrate, a results-oriented approach still has limitations and traps. LEAF can still be drawn into making essentialized claims about women's experience. This particular example will be fleshed out in Chapter 4, where I will examine the Falkner factum in depth and critique the essentialized woman LEAF presents in the factum.

\section{Conclusion}

Throughout the last century, equality has been an important rallying cry for many feminists in and out of the courtroom. In Canada, LEAF has had a significant impact on equality thinking and strategizing both in the courts and among equality-seeking groups.

LEAF's influence on sister organizations has also been profound, ${ }^{63}$ with many groups borrowing strategies from LEAF or joining forces with LEAF in specific cases. LEAF has grown through its relationship with other organizations and has undergone significant changes in the last decade so as to be more inclusive in working with and deferring to organizations like the Native Women's Association of Canada (NWAC) and the DisAbled Women's Network (DAWN). ${ }^{64}$

${ }^{63}$ Susan D. Phillips, "Meaning and Structure in Social Movements: Mapping the Network of National Canadian Women's Organizations," Canadian Journal of Political Science, 24, (1991), 757.

64 LEAF has worked in coalition with NWAC and DAWN on several cases, including Blackwater $v$. Plint,(2005) 3 S.C.R.. 3; R. v. O'Connor, (1995) 4 S.C.R.. 411 ; and Auton v. B.C. (AG) (2004) S.C.C. 78. LEAF, NWAC and DAWN attempted to get, but were denied, intervener status in the Lisa Neve case. 
The relationship between equality and feminist practice has been effective in winning some victories for women, but it has also drawn criticism from both the left and the right. The challenge before LEAF now is how to best move forward with an equality approach that reflects a diversity of women's experiences and responds to a diversity of women's needs. If substantive equality is our tool, how will we wield it? 


\section{Chapter Three}

\section{Playing Telephone: Anatomy Of A Stereotype}

"When women and other oppressed groups articulate the problem of our daily lives using the concept of rights and all that it entails, we are consciously or unconsciously squeezing our lived experience into a pre-ordained mould",65.

Sherene Razack - 1991

No matter how much we push at its boundaries or try to blur the lines, there are some inescapable truths about equality. Chapter two explored Majury and Mathen's limitations: equality is by definition comparative; it essentializes; it asserts a negative; it is gender neutral and often simplistic and it is an abstraction. But equality also has potential to improve women's lives. Women have argued for and won meaningful rights and benefits through the use of an equality analysis. Equality has worked for women. However, the question arises, at what point do the drawbacks to equality outweigh the benefits? And for whom? Is it possible to both argue inside and outside of "the preordained mould" that Razack so articulately critiques? The Bottomley/Naffine debate, touched on in Chapter One, implicitly addresses this question in relation to feminist legal theory. This chapter will briefly expand on the polarized positions of these theorists and the dilemma they present. It will then draw upon Carol Smart and Loreen Snider, as theorists who can help us to navigate the see-saw effect of forcing feminist legal theorists to pick sides on the benefits and drawbacks to equality.

65 Sherene Razack, Canadian Feminism and the Law: The Women's Legal Education and Action Fund and the Pursuit of Equality, (Toronto: Second Story Press, Feminist Publishers, 1991), 13. 


\section{Dilemma of Feminist Legal Theory}

In Shock to Thought: An Encounter (of a Third Kind) With Legal Feminism, Anne Bottomley, critiquing Ngaire Naffine's construction of "legal feminism," that feminist scholars have attempted to bind feminism into a knowable and contained scholastic form in order to constitute feminist legal theory as a distinct and credible field of academic study. Bottomley takes issue with naming feminist scholarship "legal feminism" because "such an act of naming must then be backed by evidence of a coherent identity." forced to draw out the commonalities within feminism while simultaneously downplaying those aspects of feminism that remain in contention. ${ }^{68}$ This process of molding feminist scholarship to fit the scholastic imperatives of the academy is labeled by Bottomley as a "feminist orthodoxy".

Bottomley argues that the focus or object of study for feminist legal scholarship has been confined to the ways in which law "harms" women and how to remedy this harm. She presents this focus as harmful in and of itself. ${ }^{69}$ Such a focus requires that the category of woman as an object of study must be made visible. ${ }^{70}$ Feminist scholars are forced into a line of thinking that "leads to an account of law as either letting women down by not protecting them sufficiently or, in its very construction, as itself harmful to women or exacerbating harm to women.",71

\footnotetext{
Ngaire Naffine, “In Praise of Legal Feminism," Legal Studies, 22, (2002), 177-101.

67 Anne Bottomley, "Shock To Thought: An Encounter (Of A Third Kind) With Legal Feminism," Feminist Legal Studies, 12, no.1, (2004), 37.

Ibid., 30.

Ibid., 39.

Ibid., 44.

Ibid., 45.
} 
An agenda for reform begins to take shape along this line of thinking, but such a move is problematic for Bottomley. By accepting this path as "the" rather than "a" modus operandi, feminist legal work becomes limited only to clear incidents of harm, which accordingly leaves out broader critiques of law and more fundamental engagements with law. ${ }^{72}$ Bottomley concludes that a move away from the Hegelian dialectical approach, that has to date been adopted, does not mean that strategic alliances for political reasons could not be struck, merely that we disrupt the notion that "feminist legal theory" must take a specified form and course. For Bottomley, such a disruption would open more doors for feminist engagement with law.

Ngaire Naffine responded to this critique by arguing that Bottomley's "shocking thoughts" had worrying implications. ${ }^{73}$ Naffine defended the simplification of various forms of feminist scholarship under the title "legal feminism," arguing that her simplification was necessary in order to communicate what was happening within feminist scholarship to an audience outside of the "discipline". Her goal was to "convey to a broad audience what we as legal feminist theorists do: how... we make sense of the many ways gender shapes law, how law harms women and to try to change the law so women are helped." ${ }^{, 4}$ Such simplifications and blurring of distinctions within and between feminist scholars are necessary in order to communicate directly and simply with a broad audience. To not do so would be to alienate a huge section of potential

Ibid., 42.

Ngaire Naffine, "Shocking Thoughts: A Reply To Anne Bottomley," Feminist Legal Studies, 12, no. 2, (2004), 176.

74 lbid., 176 . 
allies and women who do not have an academic background and experience with legal feminism. In other words, Naffine was attempting to "speak to the many, not the few."," Naffine defended the broad, bold, and provocative statements as necessary in order to move the feminist project forward. Responding to Bottomley's contention that she is "party to a new feminist orthodoxy which is trying to impose an inappropriate identity on feminists, ${ }^{76, "}$ Naffine asserted that "I have no desire to blunt the radical potential of feminism or to close off our options." "legal feminism is at least in part about the wrongs done to women by law ...research need not be conducted, patronizingly, at a distance, and indeed there may well be a need, as I say in my paper, for 'constructive alliances between researcher and researched'.",78 Though the Bottomly/Naffine debate is not specifically about equality, their disagreement over engagement can be translated into a disagreement over equality. Bottomley's concerns with the orthodox presentation of women in feminist legal theory echo Chapter Two's critiques of equality: a focus on sameness and the essentialization of women's experiences. Naffine's defence relates to the pragmatic issues of audience and clarity that feminist lawyers must contend with. We can see how each theorist reflects a polarized position on the equality see-saw. Naffine sits on the benefits of equality side, promoting its accessibility, currency, and radical potential, while Bottomley sits on the drawbacks of equality side and is so critical of the liberal forms of engagement that, she argues, necessarily flow from an equality approach and labeling the entire engagement a harmful form of orthodoxy. 
While legal theorists Jhappan and Buckley, discussed in Chapter Two, do address the merits and limitations of equality, it is important also to examine the implications of their theorizing for feminist practice. The Bottomley/Naffine debate provides a useful lens through which to think about this question. Legal engagement grounded in an equality framework has far reaching implications that affect the way women are presented, how cases are argued, and, as Bottomley so passionately critiques, even who is able to sit at the table or be present in the courtroom.

When transposed onto equality, this debate, even more than those specifically centered on equality, brings out interesting and challenging questions. Bottomley's characterization of a "feminist orthodoxy" has worrying implications when we apply it to the question of equality's potential. This concern over the ascription of women in the courtroom leading to prescription in the way that we present women is a key question that I am interested in examining using Carol Smart's concept of the "Woman of Legal Discourse." This construct offers a reference point for assessing the orthodoxy question in relation to women's equality litigation.

\section{A Specter on the Horizon}

In "The Woman of Legal Discourse", Smart explores the understanding of law as gendered. ${ }^{79}$ For her, this position captures the complex nature of the relationship between women and the law, that is, how gender is produced and reproduced within and between law and various other arenas within society. It helps us better understand the relationship between women and the law by analyzing the female subjects who are

79 Carol Smart, "The Woman of Legal Discourse" in Carol Smart, Law, Crime and Sexuality: Essays in Feminism, (London: Sage, 1995), 190. 
constructed through and with the assistance of "law." By law, Smart means "law as a process of producing fixed gender identities rather than simply as the application of law to previously gendered subjects." ${ }^{980}$ This view allows us to avoid being trapped into essential notions of woman, but also to avoid essential statements that imply that law affects all women equally or uniformly, or that gender itself is the difference that is privileged above all other differences. It also recognizes the interactive nature of law: gender is always being (re)made and law is part of that process. Similarly, law is always under (re)vision.

The first step in understanding law as a gendering strategy is to accept that the categories of woman and women are constructed and cannot be reduced to biological certainties: "Biological signs are not essences which give rise to a homogeneous category of women." ${ }^{81}$ Once we understand that these categories are constructions, we can begin to seek out and recognize that there is a range of strategies being used in the construction and reproduction of women and their bodies. This problemetization of the body as something that is knowable with fixed attributes is something that has been examined by Judith Butler. For Butler, categories such as male and female operate as "regulatory ideals" in which "sex not only functions as a norm, but is part of a regulatory practice that produces the bodies it governs," in this way, "sex" is productive as well as reproductive. ${ }^{82}$ Butler problematizes the static position that "sex" is given and argues that flowing from this construction of sex comes an expectation of performance that is necessary to reaffirm the constructed body. As "sex" is not fixed and the body not knowable, individuals are forced to "act" sex, this is what Butler calls "gender

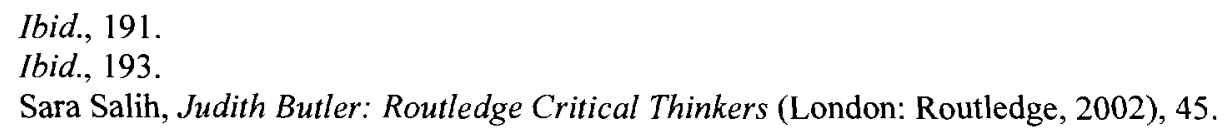


performitivity." ${ }^{83}$ Smart also adopts a similar understanding of sex by questioning the discursive production of woman as well as the various constructions of types of women. For Smart, the category of woman "represents a dualism, as well as being one side of a prior binary distinction." ${ }^{84}$ Not only is the concept of "woman" understood in relation to men, but it is also broken down into sub-comparators within the category itself. These sub-comparators serve to regulate women.

Smart uses the example of the historical discursive production of the bad mother in English law to demonstrate the historical construction and impacts of the "Woman of Legal Discourse." Her initial reference is to a statute in 1623 England that made it a penal offence for a single mother to kill her bastard infant. The assumption was that all infants who died necessarily did so as a consequence of their mother's actions. Since there were very few laws which directly addressed women, the women specific laws that did exist had a significant effect in locking-in a set of stereotypes. As Smart explains, "The unmarried mother was brought into being in law as a culpable murderer...thus we have the problematization of a specific form of motherhood...this woman is perhaps one of the first to enter into statute specifically as woman." ${ }^{.5}$

These laws not only regulated the actions of single mothers, but had an impact on all mothers, all women. The definition of bad mothering in terms of mothers without husbands inevitably leads women to regulate their behaviour in order to avoid the dangerous label of bad mother. For example, mothers might stay in an abusive relationship in order to maintain the legitimacy of the two-parent household, or women

\footnotetext{
Ibid., 45.

84 Carol Smart, "The Woman of Legal Discourse," in Carol Smart, Law, Crime and Sexuality: Essays in Feminism, (London: Sage, 1995), 193.

85 Ibid., 195.
} 
might cease to engage in pre-martial sex, or resort to dangerous abortions, or marry undesirable partners to avoid being single mothers. For Smart, legislation such as this serves to create a "Woman of Legal Discourse," a woman in law defined through legislation and constructed by law and built on assumptions and stereotypes.

We can see the fallout from regulations such as the one on single mothering. So heightened was the fear that women of loose morals might escape scrutiny that the regulations sought to trap women who might be having pre-marital sex. A litany of regulations relating to women's bodies sprang forth, including legislation against the concealment of birth, the criminalization of abortion, private prosecution against obscenity (which limited the distribution of birth control information), and even a Mental Defective Act in 1913, under which unmarried mothers were incarcerated on the grounds that they were feeble-minded ${ }^{86}$ The logic that condemned the husbandless mother in the first law flowed through each subsequent piece of legislation, building a full arsenal of laws regulating mothering. Denied birth control and abortions, women were forced to become single mothers and then punished and monitored as by definition bad mothers. All of these regulations flowed from an assumption that women need men in their lives to control them and that there is something morally and symbolically wrong with a woman who could not "keep" a man.

Through this example we see the development of culturally appropriate understandings of good mothering by means of the regulation of bad mothering. Smart argues that for each regulatory piece a binary is constructed: for example, single mothers are bad/married mothers are good. Through the harsh regulation of mothers who lack a male presence in the home, we also see the relationship between women in general and

86 Ibid., 196. 
men. The father-figure implicit in this legislation operates as a legitimizer, his absence renders the single mother illegitimate. ${ }^{87}$ The lack of regulation of the father-figure also exposes many latent assumptions about men, that is, mainly that they need no regulation in this area. Men are assumed either to be capable of being appropriate fathers without any regulation; or it is assumed that their mere presence is all that society requires of them and that simply by being present they fulfill society's expectations of fathering.

In Law as a Gendering Practice, Dorothy Chunn and Dany Lacombe expand on Smart's approach by arguing "for the utility of a social constructionist approach to feminist legal theory that also takes account of social context, structures, and history...how law intersects with other institutions and discourses in the construction of 'woman' and 'womanhood'." ${ }^{88}$ Chunn and Lacombe tease out some of the nuances of Smart's argument by further breaking down totalizing understandings of law and working with the complexity and contradictions of law that Smart identifies. The contradictions within law are best understood by making an analytic distinction between law-aslegislation and law-as-practice. "While a focus on law-as-legislation highlights the political gains achieved by feminist campaigns for change, a focus on law-as-practice often reveals the means by which a repressive social order is reproduced." 89 It is through this process of reproducing these practices and discourses in the face of feminist-inspired law reforms that the patriarchal conditions we as feminists wish to resist continue to survive.

Ibid., 197.

88 Dorothy E. Chunn, and Lacombe, Dany, Law as a Gendering Practice, (Don Mills: Oxford University Press, 2000), 3.

89 Ibid., 11. 
Smart's specter of the "Woman of Legal Discourse" allows us to understand law as productive. Not only is law influenced by the social norms and expectations surrounding it, but it manifests those norms and expectations, entrenching them. Smart's "Woman of Legal Discourse" offers us the ability to examine law from a new vantage point. Instead of looking at each law in isolation, we are required to broaden our analysis by examining what each law creates and then critically put several laws together and analyze the latent logic that informs their creation.

Conversely, we can also recognize our own complicity in creating or re-inscribing a "Women of Legal Discourse" through our engagements in the courts and in legal theory on the whole. This thesis is an exploration of the issue of feminist complicity in the creation or reinscription of the "Woman of Legal Discourse" or "Women of Legal Discourse" and whether or not this is an inevitable aspect of our participation in litigation and finally, whether the "Woman/Women of Legal Discourse" created with some feminist input are less damaging than without any feminist input.

\section{The Medium is the Message}

As feminist legal theorists, we have waded into a field with a lot of fixed rules. By virtue of accepting law as a site of struggle and the courts as our battleground, many rules and procedures must also be adopted. We do not have the luxury of constructing our own parameters for discussion and decision-making. While this does not mean that we cannot push or challenge the law, it does mean that we are not only working within a system that we find patriarchal but that the knowledge constructed here with our participation has latent meanings such that we can set off a line of reasoning or blame 
that was completely unintended. In a now famous quote, Audre Lorde stated, "The master's tools will never dismantle the master's house." ${ }^{, 90}$ Yet to varying degrees and with various end goals in mind, feminist legal scholars are attempting to do just what Lorde said was not possible. If not dismantling, we are most certainly attempting to remodel. Joining legions of other theorists, this thesis ponders Lorde's dilemma. Can we fundamentally alter/dismantle the patriarchal underpinnings in society using the patriarchal tool of law? And if not, is the less lofty goal of improving the quality and status of some women's lives and participation in society a valid trade-off for the inevitable cooptation we must live with by using the "masters tools"? In attempting to explore these questions, it is necessary to back up a step and consider how our engagement with law carries power. Put simply, how does the way we engage and what we say affect the message? Laureen Snider's work helps address these questions.

Snider has examined the pivotal role that knowledge claims can play in the courtroom. She challenges the authoritative role that experts and expertise have traditionally played in courts, urging feminist legal theorists to analyze how their own work and arguments are funneled through what she calls the knowledge-power-change nexus, which re-fashions the arguments they put forward, as in a high-stakes game of telephone in which one child starts off with one message but at the end of the line what is heard is something entirely different. In a variation on the themes raised by Lorde,

90 Audre Lorde, Sister Outsider: Essays and Speeches, (Berkley California: Crossing Press Feminist Series, 1984). 
Snider questions how counter-hegemonic our research and praxis can be as long as hegemonic filtering and refashioning are going on. ${ }^{91}$

In critiquing legal feminist engagement with the law, Snider is by no means suggesting that it is impossible to create something new within the legal sphere. On the contrary, our interventions and knowledge claims have transformative potential, the possibility of reshaping the objects about which we our writing. However, Snider cautions, "This does not happen in ways that we can predict, or have consequences we necessarily desire." $" 92$ It is essential that we understand our efforts and the efforts of other actors in the legal arena as productive and constitutive while at the same time acknowledging that we cannot control what is produced, no matter how clear we are in our goals.

Although Snider emphasizes that it is not possible to track a particular action taken by feminist legal actors and a corresponding reaction, this does not mean that we cannot track change. She writes, "It is ontologically and epistemologically impossible to find linear cause and effect links between knowledge claims, feminist or otherwise, and changes in cultural climate, law, and policy... The argument, rather, is that the commonsense beliefs of Canadian society about (for example) victimized and criminalized women have changed." 93

The results of our efforts are sometimes quite different from what we were seeking. Snider explores the example of victimized/ criminalized women. Many feminist theorists took part in the fight to resist the conception of woman as either victim

\footnotetext{
91 Laureen Snider, "Making Change in Neo-Liberal Times," in Gillian Balfour and Elizabeth Comack, eds., Criminalizing Women: Gender and (In)Justice in Neo-Liberal Times, (Halifax: Fernwood Publishing, 2006), 325.

92 Ibid., 325 .

93 Ibid., 330 .
} 
or offender. Over the years, these feminist efforts have resulted in the creation of categories like "the battered woman" and the accompanying battered woman syndrome. At the same time, there are serious feminist critiques of these categories, as there are of many other characterizations of women in conflict with the law flowing from feminist law reform fights. So the story goes: we fought to make the roles of women involved with the legal system understood as more complex, but law resists complexity and we couldn't control how the complexities we fought for would be understood and incorporated, if at all. In fighting to develop an understanding and awareness of the systemic problem of violence against women in the home, we opened a Pandora's box. I would argue that new categories coming forward, like the "battered women", are reconfigurations of old categories like the "hysterical woman" that have been dusted off and given a face lift. This is the difficultly of working within law. Since there is always some pre-existing version of a "Woman of Legal Discourse," it is very difficult to create new narratives in the court room. What often happens is a grafting of what we want onto an old stereotype that has been looming in the back of the courtroom, waiting to be pulled forward again. This seems to be an inherent stumbling block in a system based on language, precedents and old knowledge.

Snider gives us another tool that is helpful in analyzing and assessing our potential interventions. She makes a distinction between what is said and what is heard. She argues that in order to understand "the reception of knowledge claims, how they are interpreted, received, and publicized, we must shift analytical focus from knowledge produced to knowledge heard." ${ }^{\prime 94}$ We must examine the ways in which our knowledge claims "resonate" with dominant cultural agendas and how that resonance determines

94 Ibid., 326. 
what is heard. Using the above example we can see that what we said about women in conflict with the law was not what was heard. For Snider, however, the solution to such misunderstandings lies not in retreat or a renewed call for clarity - as if clarity was the problem or that all feminists could, would, or should speak with one voice - but quite the opposite. The solution lies in destabilizing expertise and creating the fallible expert. This shift opens the door "for those seen as victims and offenders, equipping them with evidence and language to resist scientific knowledge/power claims about their lives, their motivation, their realities. ${ }^{95}$ The disbursement of expertise serves two functions. First, it normalizes public scrutiny of any form of expertise as constituting "the truth". Second, it allows for power to be used by actors from various different positions.

Together with Carol Smart's "Woman of Legal Discourse," Snider's examination of the knowledge-power-nexus will assist us in unpacking the various ways in which women are presented in and through law and our own involvement in those presentations. Where Smart has given us a focal point to examine what law is creating and our role in it, Snider provides us with the tools to understand how we participate in perpetuating this "Woman of Legal Discourse" and what might be done to destabilize this fiction.

\section{Conclusion}

The Bottomley/Naffine debate led me to question whether our engagement in law using an equality framework might have become an orthodoxy. Many of the critiques of equality focus on its comparative nature, leading equality advocates to draw on absolutes in order to make an equality claim. Do the limitations within equality constitute an

$95 \quad$ Ibid., 327. 
orthodoxy? Or is it through our interactions with and expectations of equality that we create orthodoxy by internalizing the limitations as absolutes rather than challenges?

Debates like the one taking place between Anne Bottomley and Ngaire Naffine would have us take sides on equality, and yet neither side (Naffine transposed into the equality debate as the equality advocate and Bottomley the equality naysayer) feels right. Like Naffine, I think that feminists need to be able to make broad, bold, and provocative statements that are accessible to women of different backgrounds as well as to our allies. But like Bottomley, I am nervous about the logic that flows from an equality framework, a logic that essentializes female experience and seems to limit engagement to making comparisons.

Carol Smart and Loreen Snider provide us with some tools that help to break-up this stalemate. Smart's "Woman of Legal Discourse" gives us a reference point against which to assess our engagement. Instead of see-sawing back and forth over the benefits and drawbacks to an equality approach, we now have something to refer to when making strategic decisions around how to engage. When framing our factums, or drafting a claim, or writing our next article for the Canadian Journal of Women and the Law, we can contemplate what role our engagement might play in re-inscribing or problematizing a "Woman of Legal Discourse."

Snider's insights into the process of legal engagement add another useful layer of analysis. She acknowledges our agency in shaping law, but with that agency there is also a great responsibility. We cannot control how our messages will be received, but like the children's game of telephone, we can add more voices to the process and critically 
examine the receiver. The next two chapters will explore the type of calls we have been making. 


\section{Chapter Four .}

\section{Mothers, Lovers and Equality Flubbers: The Dangers of Over-Simplifying Single Mothers}

Often, we consider our actions as reactions. When the law is unfair or unequal, we react. When we see a gap in legislation that needs to be filled, we react. When a program is cut, or a benefit withheld, we react. Yet, our reactions inevitably provoke corresponding reactions, although not in linear or predictable ways. The question for feminist advocates is how we can ensure that our interventions are as positively productive as possible and are not taken away from us and used to reconstitute oppressive subject identities. In this chapter I will explore one of our reactions and examine the reconfiguration of the "Woman of Legal Discourse" as a reaction to a LEAF intervention.

As has been examined in previous chapters, law participates in the creation and perpetuation of narratives about the roles that women perform. These moral valuations and expectations run throughout legislation, policy, and cases, rewarding women who act and behave "acceptably" and punishing women who deviate. Our engagements with the law have the potential to create, re-produce and/or challenge the discourses that are used against women in their various roles: as workers, wives, widows, criminals, victims, and mothers.

LEAF intervenes in cases with the intention of challenging sexist or discriminatory narratives about women. This chapter examines one such case, Falkiner v. Ontario, and critically unpacks some of the hidden traps that an equality claim can lead us to fall into, 
exposing the siren woman of legal discourse who entices us into the trap. ${ }^{96}$ A maternal "Woman of Legal Discourse" informs the legislative rationale for the "Spouse in the House" rule that is challenged in Falkiner:

\section{Mother as a Manifestation of the 'Woman of Legal Discourse'}

As was discussed in Chapter Three in relation to the work of Carol Smart, Britain has legislation on mothering dating back to the $17^{\text {th }}$ century. As Smart pointed out, legislation and regulation dealing with any type of mother create an expectation and series of assumptions about all mothers. Laws that seemingly penalize a small fraction of mothers (for example, convicting single mothers of murder when their children die of unknown causes), serve not only to identify societal assumptions about bad mothers (eg. single), but also by implication to identify what good mothers are (eg. married). These regulations are severe. From virtually criminalizing single motherhood in their early incarnations, to denying single mothers social services in later years, these laws reward "good" mothers and punish "bad" mothers. Smart took this body of law around mothering (the legislation and regulation), and gave it a theoretical face, with her construct the "Woman of Legal Discourse." Stereotypes and moral valuations about women's proper role as mothers continue to infuse the interpretation and application of legislation that builds upon these understandings so that even today single motherhood

96 Chapter Two of this thesis examined equalities limitations at length and identified the following: 1) equality is by definition comparative; 2) equality essentializes categories; 3 ) equality is about asserting a negative, not a positive right; 4) "gender" is both over and under inclusive; 5) equality is gender neutral; 6) formal equality continues to inform equality analysis; 7) an equality analysis is either simplistic or unhelpful in pointing to a remedy; and 8) equality is an abstraction.

97 Carol Smart, "The Woman of Legal Discourse," in Carol Smart, Law, Crime and Sexuality: Essays in Feminism, (London: Sage, 1995). 
continues to carry with it a stigma that often plagues these women in the courtroom. ${ }^{98}$ Stereotyping makes up the basis of these "Women of Legal Discourse" and continued reliance and invocation of these stereotypes in law legitimize "her" presence in the courtroom.

Similarly, in Canada, the state has historically been very involved in the regulation of single mothers, either through the glaring absence of social assistance protections or through the strict regulation of assistance once it was made available. Though the first welfare legislation the state ever offered in Canada was to mothers (the mothers' allowance in 1920), this assistance was only provided to women who were widowed or whose husbands were permanently disabled. ${ }^{99}$ Even this modicum of support was limited to mothers who were deemed to be "fit and proper persons." With Canada's very first act of formalized state social assistance, we can see Smart's understanding of the indirect regulation of the bad mother, through state acknowledgement and rewarding of the women it deems the good mother. In order for the state to be certain that a bad mother did not slip into the welfare system "state workers scrutinized women's conduct in relation to various moral issues, including cleanliness, sobriety, governance of children, and especially, chastity. Any implication of sexual 'misbehaviour' could disentitle a recipient.",100

98 National Council of Welfare, Profiles of Welfare: Myths and Realities, (Ottawa: Ministry of Public Works and Services Canada, 1998), 60.

99 Women's Legal Education and Action Network, Falkiner Factum, Submitted to the Ontario Court of Appeal, December 22, 2000, 2.

100 Women's Legal Education and Action Network, Falkiner Factum, Submitted to the Ontario Court of Appeal, December 22, 2000, 2. 


\section{Social and Legal Ramifications of Having a 'Spouse' in the House}

Historically, the position of single mothers under federal and provincial social assistance legislation has been very precarious, often fueled by the types of negative stereotyping that Smart discussed. "Although the range of 'morally deserving' mothers gradually grew to include mothers who were deserted wives (1921), foster mothers (1921), divorced women (1955), and unwed mothers (1957), the law expressly continued to make eligibility conditional upon these women being 'fit and proper' or 'suitable person(s) to receive an allowance'.,

Since 1980, there have been more than six changes to Ontario's social assistance legislation just on the definition of "spouse" alone. The "Spouse in the House" rule originated in Ontario social assistance legislation in the early 1980s and defined a "spouse" as a person to whom an applicant or recipient of social assistance was married or with whom s/he was living as husband and wife. ${ }^{102}$ The rule presumed that two heterosexual individuals living together were spouses and as such, their incomes should be treated as a single unit regardless of the nature of the (assumed) couple's actual relationship. As a result of combining these incomes, many women were deemed to have a household income that disqualified them from social assistance. Pursuant to this legislation and the invasive measures used to identify cohabitation, almost 10,000 social assistance recipients in Ontario lost some or all of their benefits. ${ }^{103}$

101 Women's Legal Education and Action Network, Falkiner Factum, Submitted to the Ontario Court of Appeal, December 22, 2000, 3.

102 Applicant's Factum, Falkiner v. Ontario, Ontario Divisional Court. 2000, 9. Accessed July 4, 2006, $<$ http://www.povertyandhumanrights.org/html/factumlib/docs/flakiner/Factum\%20of\%20Applicants $\%$ $20(\mathrm{Tab} \% 2083) . \mathrm{pdf}>$

103 Canadian Statistical Assessment Services, Welfare By the Numbers, (Ottawa: Canadian Statistical Assessment Services, 2002). 
In 1985, a group of concerned recipients working with LEAF applied to the court to have this definition of "spouse" declared unconstitutional as it violated sections 7 and 15 of the Charter of Rights as Freedoms. Before the case could be heard in court, "the Ontario government approached LEAF for an out-of-court settlement." ${ }^{\text {104 }}$ Over the next two years, the government enacted changes to the General Welfare Assistance Act and the Family Benefits Act that recognized that a couple could cohabit for up to three years before the government would deem them to be "spouses". In addition, the government provided a clause which allowed recipients to demonstrate that after three years there still were no grounds to characterize their relationship with their cohabitant as "spousal" based on "the economic, social and familial aspects of the relationship." 105

The 1987 changes to the legislation did not last long. As part of the sweeping changes to welfare policies in Ontario, the Tory government led by Mike Harris amended welfare legislation pertaining to the definition of "spouse" in the Ontario Works regulation, the Ontario Disability Support Program regulation and the Family Benefits Act. Under the changed definition, a "spouse," in relation to an applicant or recipient, meant "a person of the opposite sex to the applicant or recipient who has been residing in the same dwelling place as the applicant or recipient for a period of at least three months... (emphasis added) "106. The change in 1995 effectively reinstated the old "Spouse in the House" rule that had been abandoned in 1987. The Tory government's rationale for bringing the old legislation back was "that a man living with a woman

\footnotetext{
104 Sherene Razack, Canadian Feminism and the Law: The Women's Legal Education and Action Fund and the Pursuit of Equality, (Toronto: Second Story Press, Feminist Publishers, 1991), 129.

105 Applicant's Factum, Falkiner v. Ontario, Ontario Divisional Court. 2000, 9. Accessed July 4, 2006, $<$ http://www.povertyandhumanrights.org/html/factumlib/docs/flakiner/Factum $\% 20 \mathrm{of} \% 20 \mathrm{Applicants} \%$ 20(Tab\%2083).pdf $>$

106 Definition of Spouse, Ontario Works Regulation and the Ontario Disability Support Program Regulation. Government of Ontario, 1995.
} 
would either in fact be supporting her, or should be, and that therefore she was not as 'deserving' of benefits as someone who did not have such a residential situation." ${ }^{107} \mathrm{At}$ the same time that the government amended the Family Benefits Act, it "initiated a 1-800 hotline and encouraged people, under the promise of anonymity, to report suspected welfare fraud." 108

In addition to submitting to an invasive questionnaire regarding the nature of their relationship with any co-residents, Ontario social assistance recipients also had to sign a waiver allowing an agent of the government to ask neighbours and co-workers about their personal lives. ${ }^{109}$ Caseworkers investigating the lives of social assistance recipients were encouraged to go to extreme lengths to determine whether there was a second adult present in the home. Caseworkers frequently engaged in surveillance of the comings and goings of a recipient's home and office. They were also "encouraged to conduct bathroom visits to identify toiletry items which might reveal the presence of a male visitor. In one case a worker believed that hunting magazines, a large stereo and 'masculine' clothing revealed the presence of a man in the house...in another case a woman was forced to try on a pair of unisex boots to prove that they belonged to her." Among the women denied social assistance as a result of the new definition of spouse were Sandra Elizabeth Falkiner, Claude Marie Cadieux, Cynthia Pauline Johnston, and Deborah Ann Sears. These women brought a Charter challenge to revise

107 Canadian Civil Liberties Association, Spouse in the House, Accessed July 2006, $<$ http://www.ccla.org/privacy/spouse.html $>$

108 Women's Legal Education and Action Network, Falkiner Factum, Submitted to the Ontario Court of Appeal, December 22, 2000, 4.

109 Canadian Civil Liberties Association, Spouse in the House, Accessed July 2006, $<$ http://www.ccla.org/privacy/spouse.html $>$

110 Applicant's Factum, Falkiner v. Ontario, Ontario Divisional Court. 2000, 9. Accessed July 4, 2006, $<$ http://www.povertyandhumanrights.org/html/factumlib/docs/flakiner/Factum $\% 20 \mathrm{of} \% 20$ Applicants $\%$ $\underline{20(\mathrm{Tab} \% 2083) . p d \mathrm{p} P}$ 
the definition of spouse contained in the Family Benefits Act. ${ }^{111}$ According to a LEAF factum, the applicants shared several features. All were single mothers who had been living with someone of the opposite sex for less than a year. All had experienced violence at the hands of a past partner. All had been given to understand that cohabitation with someone of the opposite sex would not affect their family benefit eligibility until such time as they decided to acknowledge each other as spouses or three years had passed. At the time of their disqualification from social assistance, these women did not consider themselves to be spouses. ${ }^{112}$ With the goal of returning to a more accurate understanding of "spouse," the applicants sought to reinstate the 1987 definition.

On appeal from a decision of the Social Assistance Review Board which had overturned the Director of Income Maintenance's reclassification of the applicants as spouses under the Act, the Ontario Divisional Court ruled in favor of the applicants' petition. The Court found that the definition of "spouse" in s.1(1)(d) of Regulation 366 under the Family Benefits Act was unconstitutional because it violated s.15 of the Canadian Charter of Rights and Freedoms and could not be saved under s.1. ${ }^{113}$ The Government of Ontario appealed to the Court of Appeal, where the appeal was struck down, upholding the decision that the Act's expansive definition of spouse was

11 Paul Thomas was also an appellant in the case. Mr. Thomas was a mentally disabled man who lived with a female friend and caregiver. The Director of the Income Maintenance Branch of the Ministry of Community and Social Services deemed the two to be spouses. The two appeals were separated by the courts.

112 Applicant's Factum, Falkiner v. Ontario, Ontario Divisional Court. 2000, 9. Accessed July 4, 2006, $<$ http://www.povertyandhumanrights.org/html/factumlib/docs/flakiner/Factum\%20of\%20Applicants\% 20(Tab\%2083).pdf $>$

113 Court of Appeal for Ontario. Judgment - Falkiner v. Ontario, May.13, 2003. Accessed May 10, 2007, $<$ http://www.ontariocourts.on.ca/decisions/2002/may/falkinerC35052.htm $>$ 
unconstitutional. ${ }^{114}$ The Government of Ontario undertook to appeal to the Supreme Court of Canada, but desisted after a provincial change in governing political parties.

\section{Cause and Effect - Single Mothers Singled Out}

Although on its face the definition of spouse applied equally to all welfare recipients in Ontario, in effect it was used almost exclusively against single mothers, "Of all welfare recipients, only single parents - of whom $95 \%$ are women - are categorically denied assistance in their own right when they are deemed to be living with a 'spouse'."115 Thus, the practical application of the "Spouse in the House" rule places it in the same regulatory context as the mothering regulations discussed by Smart. This rule not only re-enforces moral valuations about "unwed" mother's sexual relations, but in fact uses such valuations to reaffirm a maternal "Woman of Legal Discourse." The "Spouse in the House" rule exposes several assumptions that underpin the inscription of this maternal "Woman of Legal Discourse." First, the rule assumes that single mothers require special regulation. The regulation targets "single" individuals and attempts to regulate their relationships. Second, by virtue of ascribing spousal status, the regulation assumes that those regulated are untrustworthy and need to be monitored. Generally, individuals wishing to be spouses can marry or are declared to be common law after three years of cohabitation (which is at least a much longer period). The "Spouse in the House" regulation denies welfare recipients the ability to define their own relationships and

${ }^{114}$ Ontario Court of Appeal. Stay - Falkiner v.Ontario, September 22, 2000. Accessed July 4, 2006, $<$ http://www.ontariocourts.on.ca/decisions/OntarioCourtsSearch_VOpenFile.cfm?serverFilePath $=\mathrm{d} \% 3$ A $\% 5$ Cusers $\% 5$ Contario $\% 20$ courts $\% 5$ Cwww $\% 5$ Cdecisions $\% 5$ C $2000 \% 5$ Cseptember $\% 5$ Cfalkiner $\% 2 \mathrm{E}$ $\underline{\mathrm{htm}}>$

115 Women's Legal Education and Action Network, Falkiner Factum, Submitted to the Ontario Court of Appeal, December 22, 2000, 2. 
assumes that they will abuse the welfare system if given the opportunity. A third assumption is that cohabitation necessarily involves financial dependence or interdependence. If there is a male partner in the home, there is an assumption that the woman will be economically dependent upon him. And finally, the regulation effectively prohibits single mothers from having casual live-in sexual relationships.

These laws and regulations relating to mothering can be understood if we examine the social role that mothers have historically played as moral figureheads, both inside the family and in society as a whole. The strict regulation of single mothers reinforces the assumption that these women are undesirable aberrations, simultaneously sending a message to all mothers about their "proper" moral role. Though single mothers have always existed, the creation of a moral panic about single motherhood during key points in history has allowed the state to shift blame for social ills away from government and back into the private sphere. ${ }^{116}$ In Smart's example of the prosecution of single mothers whose children died in the $17^{\text {th }}$ century, we see the state offloading responsibility for those deaths onto single mothers, when clearly the deplorable social and economic conditions of the working class in $17^{\text {th }}$ century England would have played a large part in child mortality. Even today, the blame for many of society's problems is placed on the breakdown of the family, that is on the women who "cause" those breakdowns and on the single mothers they become as a result.

There is a lot at stake in the control of attitudes surrounding mothering. In particular, there is a lot of power and legitimacy to be found in invoking "mothering" as long as it is the right kind of mothering performed by "good mothers". From the first

116 Margaret Jane Hillyard Little, No Car, No Radio, No Liquor Permit: The Moral Regulation of Single Mothers in Ontario, 1920 - 1997, (Toronto: Oxford University Press, 1998), xi. 
wave maternal feminists who advocated for suffrage, prohibition, and the sanctity of the family to today's REAL Women, a right wing organization that argues that "the fragmentation of the Canadian family is one of the major causes of disorder in society . today, $" 117$ the specter of the good mother has been a powerful rallying tool. Often such invocations offer their wielder access to state endorsement, government funding, and broad-based support in religious and conservative media. ${ }^{118}$ The single mother on the other hand is maligned and abandoned.

\section{LEAF's Intervention in Falkiner}

Although the above presentations of mothers are made by the conservative right, there are also some deeply entrenched problems in the ways in which mothers are presented by feminist legal theorists. There has historically been a pull on feminist legal theorists to make their representations of women coincide with pre-existing dominant narratives in an attempt to make sure that the feminist-represented woman is still positively recognizable to the legal decision maker, perceived as neither alien nor a threat. Thus, conservative versions of good mothers often find resonance in feminist reconstructions. Even when we have attempted to step outside traditional representations, old stereotypes seem to reassert themselves. LEAF fell into this trap in Falkiner. By attempting to broaden the boundaries of acceptable mothers without

117 R.E.A.L. Women, "Official Website", Accessed February 2007, $<$ http://www.realwomenca.com/about.htm>

118 Despite their adamant criticism that the Status of Women and the Women's Programme funds only pro-choice feminist organizations, REAL Women of Canada also receives government funding. In light of the recent cuts and restrictions placed on Status of Women Canada, it may be that REAL Women will be one of the only women's groups able to qualify for funding. Their website acknowledges the funding at $<$ http://www.realwomenca.com/newsletter/2006_may_jun/article_7.html > 
challenging the criteria, the maternal "Woman of Legal Discourse" inscribed in the social assistance legislation being challenged was re-affirmed by LEAF.

In Falkiner a rich array of narratives about mothering is put forward. There is the historical stereotype of the bad, single mother that underlies the discriminatory way in which this particular piece of legislation attempts to monitor and regulate single mothering. There are the real experiences of the four applicants. There is LEAF's presentation of single mothers. There is an understanding of welfare recipients put forward by the Canadian Civil Liberties Association. And there is the presentation of single mothers made by the Ministry of Community and Social Services in support of the legislation. Although these multiple and competing narratives all play a role in constituting and reinforcing notions of both the good and the bad mother, I will only explicitly explore the feminist narrative, the one that we would anticipate would be the most counter to the "Woman of Legal Discourse."

In Falkiner v. Ontario, LEAF, in their role as intervener, examined the legislative history of social assistance and then situated social assistance and the "Spouse in the House" regulation in their social, economic, and legal contexts. They attacked the stereotyping that is often found underpinning social assistance regulations, arguing that the regulation of social assistance has historically been premised on the false presumption of a "typical" idealized family in which the male figure is the family earner and the female figure is the dependent care giver. With respect to families who fall short of this ideal, it is only in scenarios where the female is considered to be morally deserving and it 
is clear that the male "breadwinner" is absent through no fault of the female that the state will step in to assume the male role as financial provider. ${ }^{119}$

In addressing the social and economic context in which the regulations operate, LEAF argued that the majority of welfare recipients in Ontario are women (most of whom are single mothers and as such stigmatized). These single mothers are economically more vulnerable than men and socially and economically disadvantaged. As such, single mothers are disproportionately affected by the regulations. LEAF relied upon these points in order to make the case that single mothers are an analogous group ${ }^{120}$ under section 15 of the Charter of Rights and Freedoms, as the Nova Scotia Supreme Court had recognized in $R$. v. Rehberg in $1993 .^{121}$

Members of groups seeking Charter protection can argue that they are analogous to the groups listed in section 15 and thus should be included within the protection of section 15. In making this argument, the group claiming to be analogous has to show that they are distinct, identifiable, and differently affected and have experienced historical disadvantage. The need to demonstrate that single mothers are an analogous group is what put LEAF in the position of having to articulate the boundaries, characteristics, and features of the group "single mothers". In making this claim, LEAF drew upon common stereotypes in law and society. The stereotype of single mothers on social assistance assumes long-term welfare dependence, youth, promiscuous behaviour, many children,

119 Women's Legal Education and Action Network, Falkiner Factum, Submitted to the Ontario Court of Appeal, December 22, 2000, 2.

120 Section 15 of the Charter prohibits discrimination based on race, national or ethnic origin, colour, religion, sex, age, or mental or physical disability. But unlike human rights legislation, the Charter list is not closed but allows for the addition of categories of discrimination as analogous grounds based on their similarities to the listed grounds. For example, sexual orientation is not expressly included in section 15, but it has been read in as an analogous ground.

121 R. v. Rehberg [1993], 127 N.S.R. (2d) 331 (N.S.S.C.) at 351-352 
poor parenting and a propensity for fraud. ${ }^{122}$ It is these assumptions that LEAF attempted to counter when presenting their own description of single mothers. They described single mothers on social assistance as older (in their mid to late 20s and 30s) and on average having fewer children than women not on welfare. They challenged the myth of welfare dependency by arguing that "most single mothers use welfare only once and for a relatively short period of time." ${ }^{123}$ They characterized the usage as circumstantial and temporary, pointing out, "Half of single mother recipients use welfare following divorce or separation and rely on it for less than two years. As an overall average, single mother recipients exit the welfare system within 3.5 years to 4 years." 124

In some ways, this presentation of single mothers was progressive. As was LEAF's intention, it challenged many of the stereotypes of single mothers that have historically influenced the makeup of regulations like those in the Family Benefits Act. However, this alternative description of single mothers performed a constitutive function. LEAF was attempting to broaden the boundaries of the good mother, rather than problematizing the construct. This strategy served to reaffirm the maternal "Woman of Legal Discourse." LEAF was only trying to shift the norm. They opened the door for more women to enter the good mother category, but left the bad mother binary intact. There are two key problems that stem from LEAF's approach. They ignore the diversity among and between women (and in particular, woman on social assistance) and their focus on the "good" characteristics of mothering leaves negative characterizations

122 National Council of Welfare, Profiles of Welfare: Myths and Realities, (Ottawa: Ministry of Public Works and Services Canada, 1998), 1.

123 Women's Legal Education and Action Network, Falkiner Factum, Submitted to the Ontario Court of Appeal, December 22, 2000, 8.

124 Women's Legal Education and Action Network, Falkiner Factum, Submitted to the Ontario Court of Appeal, December 22, 2000, 8. 
relatively intact. These negative characterizations continue to implicitly operate as the binary to the highlighted positive features, thus continuing to abandon those single mothers who possess some or all of the negative characteristics.

\section{The Raceless, Faceless Body vs. The "Bad" Woman}

The description that LEAF provided of single mothers on social assistance virtually ignored the many and varied differences among single mothers. With the exception of one brief proviso stating that " ... single mothers on welfare often experience multiple layers of discrimination based on grounds enumerated in s. 15(1), including sex, race, disability and age, and grounds analogous to them, such as poverty," examination of the multiple ways, beyond sex and class, in which single mothers face barriers to equal treatment in our society. In the entire factum, the above paragraph is the only mention of these complicating differences.

Elizabeth Spelman describes the kind of proviso that LEAF used as the "ampersand problem" in feminist thought. When we simply list off a series of possible differences between women, as LEAF did in their proviso noted above, we paint a picture in which individuals facing multiple forms of oppression are seen as additionally

oppressed instead of differently oppressed. ${ }^{126}$ Spelman argues that this "additive analysis of identity and of oppression can work against an understanding of the relations between

125 Women's Legal Education and Action Network, Falkiner Factum, Submitted to the Ontario Court of Appeal, December 22, 2000, 15-16.

126 Elizabeth Spelman, "Gender \& Race: The Ampersand Problem in Feminist Thought," in K.K.

Bhavnani, ed. Feminism and 'Race', (Ottawa: Ottawa University Press, 2001), 74. 
gender and other elements of identity." ${ }^{127}$ By not properly addressing the role different barriers can play, those barriers remain intact, unchallenged, and barely acknowledged.

As a consequence of blurring the differences between women, we fail to adequately acknowledge the different social roles that people occupy, thus treating intragroup equality as less important than equality between groups. ${ }^{128}$ This approach prioritizes the characteristics that these women have in common and dismisses/diminishes the rest.

LEAF's approach in this factum echoes Anne Bottomley's concern with feminist orthodoxy. Here we can clearly see that LEAF has drawn out the commonalities amongst the applicants and has erased the differences, not only between the applicants, but between all single mothers on income assistance. ${ }^{129}$ In an effort to create a homogeneous "group," LEAF latched onto what is held in common, disregarding what is different among mothers. This leads to the second concern with LEAF's strategy in Falkiner - the question of who is left behind.

One of the problems with the "Woman of Legal Discourse" is that the good woman needs a counterpoint - bad woman - in order to be recognized as good. By accentuating certain characteristics as good, other characteristics (those that are either not discussed or that are the opposites of those noted as good) are implicitly labeled as bad. Other stereotypes that women face, including those based on their race, religion, sexual orientation, or ability, will thus continue to be used to characterize these other single

127 Ibid., 74.

128 Davina Cooper, "Like Counting Stars: Re-Structuring Equality \& the Socio-Legal Space of SameSex Marriage," in R. Wintemute and M. Andenaes, eds., Legal Recognition of Same-Sex Partnerships: A Study of National, European and International Law, (Portland: Hart, 2001), 76.

129 Anne Bottomley, "Shock To Thought: An Encounter (Of A Third Kind) With Legal Feminism," Feminist Legal Studies, 12, no.1, (2004), 30. 
mothers as bad. LEAF is simply replacing a negative stereotype with a positive stereotype.

\section{No Evil, Hear No Evil}

Loreen Snider's knowledge-power-change nexus is helpful in examining some of the consequences of LEAF's presentation of single mothers in Falkiner. LEAF attempted to de-bunk the myth that single mothers were promiscuous women who languished on welfare for long periods of time, draining the system while popping out baby after baby. However, Snider calls upon us to consider how our interventions are heard. By arguing that most single mothers do not fit the stereotype, the negativity of the stereotype is perpetuated, even re-enforced. Implicitly, LEAF's description of single mothers reinforces the assumption that good mothers get off welfare quickly; good mothers have few children; young mothers are less trustworthy; and perhaps most damaging, welfare is (or at least should be) transitional.

When we combine these assumptions with the absence of any examination of the multiple forms of discrimination that some women face, a disturbing gap begins to take shape. If we understand the maternal "Woman of Legal Discourse" in light of LEAF's intervention in Falkiner, we can see who does not fit the mold: single mothers with many children; single mothers who access welfare many times; or single mothers who stay on welfare for long periods of time or even indefinitely. Women who face systemic discrimination due to race, religion, and/or ability are more likely to need access to social assistance more frequently and for longer periods of time as a result of societal barriers to 
other options. Yet, this complexity was not addressed in LEAF's factum, leaving intact the perception that these women are bad mothers.

\section{Conclusion}

The decision in Falkiner and the resulting revised definition of spouse were a victory. Many women were able to regain access to social assistance as a result of the decision, while at the same time maintaining a certain amount of agency in defining their intimate relationships. However, many women who could not fit into the essentialized woman portrayed by LEAF in Falkiner were left behind by the factum. In attempting to present a common experience, LEAF ignored the different barriers that many women face, and, as such, left those women stereotyped and vulnerable. LEAF's factum in Falkiner raises the question of whether it is possible to apply an equality approach that does not essentialize the presentation of women. How can we overcome or compensate for the limitations within equality in such a way as to use equality to challenge the "Woman of Legal Discourse?" The problem here is not that we make inaccurate generalizations, but that we make generalizations at all and thereby serve to further marginalize already marginalized women who do not fit the generalized picture. The question that Bottomley's critique raises is whether there is a way to avoid this dilemma. 


\section{Chapter Five}

\section{Challenging Binaries: The Radical Potential of an Equality Framework}

This chapter takes some of the challenges raised by the Falkiner factum and examines how the problem of essentialism and discursive hegemony has been contested in other interventions. Interventions in two cases - Mossop v. Canada (Attorney General) $^{130}$ and Winnipeg Child and Family Services (Northwest Area) $v G(D F)^{131}$ - are helpful in identifying openings for us to challenge the "Woman of Legal Discourse." Though all three cases employed an equality framework, with the corresponding limitations previously identified, both Mossop and $G$ used equality to contest the legal categories at issue instead of affirming them.

The Canadian Charter of Rights and Freedoms requires court challengers to fit themselves into Section 15's listed or analogous categories in order to demonstrate a case for equality. In Falkiner, this led LEAF to construct "single mothers on welfare" as a legal category in order to argue that single mothers were disproportionately negatively affected by the "Spouse in the House" rule. LEAF was clearly attempting to disrupt damaging stereotypes about single mothers in Falkiner. They thoughtfully and carefully detailed the many myths about single motherhood and located single mothers in their historical and social context. On the surface, such a carefully presented critique appears to challenge assumptions about mothering. However, by re-packaging some single

${ }^{130}$ Mossop v. Canada (Attorney General), [1993], 1 S.C.R. 554

131 Winnipeg Child and Family Services (Northwest Area) v. G. (DF), [1997], 3 S.C.R. 925 
mothers as good mothers and implicitly accepting the bounded concept of good mothering, the assumptions that make-up the maternal "Woman of Legal Discourse" in Falkiner go largely unchallenged.

Given the constraints that LEAF was under in making their analogous claim in Falkiner, was it possible to challenge the definition of single mothers on welfare in a way that did not leave women behind? In large part, the problem of ascription seems to be directly related to description. When we make a s.15 equality claim, we often fall into the trap of prescribing the makeup of our applicants. In arguing that a social group is being unequally treated, it falls upon us to create and define that legal group, thus forcing court challengers to draw clear lines where socially and historically these categories are more fluid and the lines (when there are lines) are much more blurred. Such legal rules ironically force court challengers to create the very thing they are arguing against - a stereotype. One strategy to try to evade the dilemma of description/ascription would be to refuse to provide an alternate definition of the applicant group or of the comparator group into which the applicants are trying to gain entry. This was the strategy that the coalition interveners ${ }^{132}$ in Canada (Attorney General) v. Mossop attempted to employ.

132 Equality for Gays and Lesbians Everywhere, Canadian Rights and Liberties Federation, the National Association of Women and the Law, the Canadian Disability Rights Council and the National Action Committee on the Status of Women formed a coalition in Mossop. From here on in, I will refer to this coalition as the interveners. There were, however, a second group of interveners who opposed extending benefits to same-sex partners; these were Focus on the Family, the Salvation Army, REAL Women, the Evangelical Fellowship of Canada, and the Pentecostal Assemblies of Canada. (Mossop $v$. Canada (Attorney General), [1993] 1 S.C.R. 554). I will not be making reference to them as interveners in this thesis. 


\section{Canada (Attorney General) v. Mossop}

Brian Mossop, a federal government employee, was denied bereavement leave to attend the funeral of his long-time same-sex partner's father. The Collective Agreement stated that employees could take up to four days when a member of one's "immediate family" passed away. Mossop challenged the opposite sex definition of spouse and the definitions of family that flowed from it in his collective agreement. ${ }^{133}$ The Human Rights Tribunal ruled in favour of Mossop and ordered the collective agreement be changed to reflect same-sex relationships. The Attorney General challenged the tribunal's ruling and the case was overturned by the Federal Court of Appeal and then heard by the Supreme Court of Canada, where Mossop's lawyer argued that the denial of "bereavement leave" violated his human rights.

Like Falkiner, Mossop was making an equality claim, arguing that same-sex relationships exist and need to be recognized as important, meaningful relationships that deserve to be treated equally and respectfully. Unlike Falkiner, the interveners in Mossop steered away from arguing that Mossop's relationship fit the dominant relationship model; that is that his relationship with his partner was "just like" heterosexual relationships.

The interveners in Mossop deliberately chose not to provide an alternative definition of family which would be used to compare and include Mossop's relationship. Instead, the factum took a more postmodern position through "its insistence on the falsity

${ }^{133}$ Jody Freeman, "Defining Family in Mossop v. DSS: The Challenge of Anti-Essentialism and Interactive Discrimination for Human Rights Litigation," The University of Toronto Law Journal, 44, no. 1, (1994), 50. 
of universals; its refusal to choose between dichotomized alternatives; its emphasis on the indeterminacy of interpretation; and its reliance on contextualized arguments, ${ }^{, 134}$

Instead of reinforcing the notion of a "type" of couple that is appropriate for family recognition, the coalition made a "conscious attempt in its factum to discredit the pervasive notion that only heterosexual couples with children are families, while resisting the temptation to supply the Court with a new universal definition." 135 This rejection of a definition for family was a difficult step for the coalition. In her accounting of the drafting of the Mossop factum, Jody Freeman discussed the challenge of setting conceptual limits and the debate around requirements. Within the coalition there was a real fear that the refusal to define family would affect Mossop's case for bereavement leave benefits and was thus impractical because the courts would never accept such flexibility. A compromise was struck within the coalition to attempt to articulate a position whereby "the definition of family need not be meaningless or arbitrary, but should be linked to the purpose of the legislation, or the benefit at issue."136 This approach was meant to lay the groundwork for a fluid situational interpretation of family.

The coalition abstained from providing a definition of family, thus challenging the normalcy of heterosexuality by not acknowledging it. This refusal to define also serves to protect couples that might fall outside of the norm. Relationship groupings that are not "just like" regular couples are not left behind by the Mossop factum. Space is left for them to argue for inclusion and to demonstrate that they fit within the situational interpretation of family in terms of the purpose of the particular legislation or the benefit.

Ibid., 48.

Ibid., 47.

Ibid., 65. 
I find the story of the Mossop intervener factum interesting in light of the struggles over articulation that feminists continue to grapple with in and out of the courtroom. The tensions within the Mossop coalition are very similar to those raised in the Bottomley / Naffine debate. Disagreement over tactics and language, equality and essentialism continue to play a significant role in feminist legal discussions because of the possibilities and corresponding limitations of these tools/methods.

On the one hand, like Bottomley, there is concern that the parameters placed on feminists when engaging with the law have the potential to force us to pigeonhole the women that we represent. On the other hand, feminists like Naffine argue that we have to be accessible and persuasive. Our language must be understandable and our ideas must resonate with our audience and, perhaps, though Naffine does not say it, ${ }^{137}$ our cases need to be winnable.

Naffine's call for accessibility and clarity in feminist theory relates to a larger concern in feminist circles over the usefulness and power of identity. Categories such as women, person of colour, disabled or lesbian are not only discriminatory constructs of the society that we live in but are also categories about which their members have, through struggle, managed to carve out a corresponding understanding that the people who fall into these categories are and have been oppressed and that oppression deserves to be rectified.

There is also a strategic usefulness that comes from strength in numbers and the power of being part of a group. Though these categories are often accepted for these

${ }^{137}$ The Naffine/Bottomley debate was a debate over the creation of feminist legal studies and was restricted to theoretical writings on feminist legal strategy. So, although "winnability" does not enter directly into the debate, it certainly becomes a concern when the debate is transferred into the courtroom. 
reasons, the blurring of individual identity, background and experience into the group tends to force group members to prioritize one identity feature over another. And this runs us into essentialism, the concern that all of the various complexities that are part of the human experience can be boiled down to a single category for easy sorting. This is a major issue that women of colour who are asked to prioritize their womanhood in order to be good feminists have pushed to the forefront of the feminist agenda. Thanks to the contributions of feminists of colour like Audre Lorde, Angela Harris, and bell hooks, we are aware of such reductionism; unfortunately, we are far from eradicating such generalizations in our work. ${ }^{138}$ The central question that comes out of Mossop, Bottomley, and Naffine is how do we, how can we promote group based equality without essentialism. ${ }^{139}$

The lesson we can take away from the Mossop factum is that it is possible to reject essentialist archetypes (or at the very least complicate these archetypes) by refusing to present an alternative archetype. And personally, as a very fearful postmodern-let, it was comforting to see that we can refuse to define a major concept like "family" and that nothing catastrophic happens. A gapping hole of nothingness did not envelope the factum just because the category under scrutiny was not reaffirmed. At the same time, other categories, which under different circumstances might be equally problematic, escaped the Mossop factum unchallenged. The interveners made a strategic decision about which categories to accept as is and which ones to problematize. Brian Mossop is still identified as a homosexual man in a homosexual relationship; it is the related

138 Marlee Kline, "Race, Racism and Feminist Legal Theory," Harvard Women's Law Journal, 12, (1989), 115.

139 Or at least an aware essentialism. 
category, family, that is not defined. The interveners took control over which legal discourses they were willing to participate in and which ones they wished to challenge.

It is important here to note that Mossop lost his human rights case. The Supreme Court found that Mossop was not discriminated against on the basis of family status and that although he was discriminated against on the basis of his sexual orientation, such discrimination was not at that time prohibited under the Canadian Human Rights Act. ${ }^{140}$

The loss in Mossop raises some interesting questions, especially with the advantage of fourteen years hindsight. Many theorists have reflected on what counts as winning ${ }^{141}$ and have determined that we can often find victory in defeat. Legal cases promote public discussion of the issues raised and the arguments put forward by the parties, and interveners contribute to public understanding of what is at stake and why it matters. A case that is lost in the courts can give rise to public outcry and to major legislative reform. ${ }^{142}$ Arguments that are lost in one case may pave the way to a more receptive court when similar arguments are raised in future cases. ${ }^{143}$ Mossop was a victory in its process, in the way in which it brought different groups together to discuss how the current definition of family affected them. In refusing to define "family," the interveners sought to problematize this norm not just for same-sex couples but for everyone. This was also the beauty of Mossop -- that before this case was heard the

140 Canadian Human Rights Act, R.S.C. 1985, c. H-6

141 Sherene Razack, Canadian Feminism and the Law: The Women's Legal Education and Action Fund and the Pursuit of Equality, (Toronto: Second Story Press, Feminist Publishers, 1991), 27; and Christopher Manfredi, Feminist Activism In The Supreme Court: Legal Mobilization and the Women's Legal Education and Action Fund, (Vancouver: University of British Columbia Press, 2004), xviii.

142 The public outcry after cases like R. v. Seaboyer; R. v. Gayme, [1991] 2 S.C.R. 577; and Murdoch v. Murdoch [1975] 1 S.C.R. 423 were decided, led the federal government to institute better provisions for rape victims and provincial governments to revive matrimonial property regimes.

143 With the benefit of hindsight, we have now seen several major breakthroughs in the legal status of same-sex relationships, most notably the 2004 Supreme Court of Canada Reference re. Same-Sex Marriage which found that same-sex couples did indeed have the Charter right to marry: Reference re Same-Sex Marriage, [2004] 3 S.C.R. 698, 2004 SCC 79. 
stereotype was that gay couples have "different" relationships. The interveners argued that everybody has "different" relationships, but that those differences do not mean that the relationships are of lesser value. The gift of the Mossop factum is not in the outcome of the case itself, but in the knowledge that it provides us with, that we can challenge dominant discourses by refusing to engage in them on their terms. For the purposes of this paper that means that we might be able to avoid the "Women of Legal Discourse" by refusing to define her.

We can see a similar strategy at work in the case of Winnipeg Child and Family Services vs. $G(D F)$ (The $G$ case). ${ }^{144}$ Whereas the interveners in Mossop refused to define family, the interveners ${ }^{145}$ in the $G$ case refused to define mother. More specifically, they refused to define "good mothers" in order to protect their applicant, who it was unlikely could be made to fit even an expanded version of this idealized good mother mold. The intervener's factum reveals the flexibility that is provided once the obligation to package $\mathrm{G}$ as a version of the idealized "Mother of Legal Discourse" is rejected.

The $G$ factum is fascinating in light of the theoretical mine-fields the interveners were forced to walk in arguing her case. In her article, "Disarticulating Liberal Subjectivities: Abortion and Fetal Protection", Lealle Ruhl provides important insight into the complex narratives woven through the $G$ case. ${ }^{146}$ As a background to these narratives, a cursory discussion of the relationship between the pregnant subject and

144 Winnipeg Child and Family Services (Northwest Area) v. G. (DF), [1997] 3 S.C.R. 925.

145 For the purposes of this thesis, the term interveners is used to describe the intervention of the Women's Legal Education and Action Fund and their coalition partners in G. As well as the coalition that argued for Mossop's right to bereavement benefits in Mossop.

146 Lealle Ruhl, "Disarticulating Liberal Subjectivities: Abortion and Fetal Protection," Feminist Studies, 28, no. 1,(2002), 37. 
her/the fetus is necessary in order to identify the potential traps associated with the language used in $\mathrm{G}$.

\section{Disrupting Binaries}

Ruhl examines the impact of the rhetoric of choice on achieving reproductive autonomy for women. Ruhl argued that although this discourse has been an effective organizing tool and a focal point that can bring women of very different political and class groups together, it is essential that we recognize the not-so-latent variable of liberalism at play in the concept of choice and the effects this has on making women vulnerable to other liberal critiques that come part-and-parcel with the concept of choice.

For Ruhl, there are several consequences of using "choice" as our means of engagement with reproductive autonomy. First, such an argument creates an adversarial relationship between the woman and the fetus. Liberalism is unable or unwilling to contemplate the pregnant woman as anything but a subject divided against herself. The language of individual choice inevitably forces the pregnant woman into an adversarial relationship with her fetus when the interests of one conflict with the interests of the other. ${ }^{147}$ Ruhl argues that "when the fetus is viewed as a being separate from the pregnant woman, the stage is set for scrutinizing the behavior of pregnant women for the harm they may be doing to their fetuses.",148

Second, through the use of choice, responsibility and blame arise as counterweights. For Ruhl, choice brings with it a corresponding assumption of responsibility

147 Already we can see tension in subject status in my own struggle with language as I attempt to avoid the trap of fetus subjecthood or of giving equal weight to fetus/ pregnant interests when my intention is to only acknowledge the subject status of the pregnant woman.

148 Lealle Ruhl, "Disarticulating Liberal Subjectivities: Abortion and Fetal Protection," Feminist Studies, 28, no.1,(2002), 37 . 
that comes with making the "choice" to have a child. The material conditions necessary for meaningful options in reproduction are ignored in favour of a set of assumptions about appropriate behaviors expectant "mothers" should act out. The argument, says Ruhl, "runs as follows: having made the free decision to continue with a pregnancy (a pregnancy that was presumably willed to begin with), a woman surrenders her individual rights to the needs of the fetus for the duration of the pregnancy." 149 That is her "choice." Such an argument neglects the social and economic factors that prevent such decision making from being free.

Ruhl's examination of choice and liberalism fits well into a discussion of the various narratives that feed into the "Woman of Legal Discourse". As Laureen Snider's knowledge-power-change nexus would indicate, ${ }^{150}$ rhetoric like "choice" cannot simply be used in the way that "we" might want to use it; a lot of baggage comes on board. Blame and responsibility are an inextricable part of choice because they are specifically part of the corollaries to choice in liberalism's narrative. One has free choice and as a consequence must take responsibility for one's decisions; to not do so is to fail as a good and well-rounded liberal actor, thus leading to blame when one does not "live-up to" one's responsibilities.

Pro-choice activists have been careful to reject the bifurcated subject paradigm that is often picked up by the Christian Right. But, regardless of how precisely the choice argument is made, the blame counterweight seems to be an inseparable part of the liberal logic of choice.

149 Lealle Ruhl, "Disarticulating Liberal Subjectivities: Abortion and Fetal Protection," Feminist Studies, 28, no.1,(2002), 43.

150 Snider, Laureen, "Making Change in Neo-Liberal Times," in Gillian Balfour and Elizabeth Comack, eds., Criminalizing Women: Gender and (In)Justice in Neo-Liberal Times, (Halifax: Fernwood Publishing, 2006). 
An extreme example of the transition from choice to blame is found in the Supreme Court of Canada decision in Winnipeg Child and Family Services vs $G(D F) .{ }^{151}$ Ruhl examined this case in an effort to point out this connection. I would like to take her inquiry a step further by examining the intervener's use of equality instead of choice in relation to the intervener's refusal to define mothering in their attempt to avoid the blame of bad mothering of a fetus.

\section{Background}

G. was a young First Nations woman who was addicted to sniffing glue. In 1996, she became pregnant with her fourth child. The permanent disability of two of her previous children had been attributed to her addiction, and those children, along with a third, had previously been made permanent wards of the state. In response to G's pregnancy, the Director of Child and Family Services approached the courts and requested that $\mathrm{G}$ be ordered into his custody and held in a medical treatment facility until the birth of her fourth child under the auspices of the court's parens patriae jurisdiction. The lower court granted the order, but the decision was overturned by the Manitoba Court of Appeal. The case was further appealed to the Supreme Court of Canada.

At the Supreme Court, the majority rejected the appeal, ruling that parens patriae could not be extended to the unborn as "the law of Canada does not recognize the unborn child as a legal person possessing rights." 152 The majority found that to extend the application of the rule to the unborn would mark a major departure from the existing rule, giving rise to complex consequences.

151 Winnipeg Child and Family Services (Northwest Area) v. G. (DF), [1997] 3 S.C.R. 925.

152 Winnipeg Child and Family Services (Northwest Area) v. G. (DF), [1997] 3 S.C.R. 925. 
In this particular case, the two dissenting judges, Sopinka J, writing for himself and Major J, held that the "jurisdiction available under parens patriae to act in the best interests of a child should include the power to act in the best interests of a fetus." 153 Both judges rejected the "born alive" rule (which requires a fetus to be born alive before any rights accrue) as being anachronistic and instead picked up the blame argument that Ruhl exposed as inherent in liberalism's approach to the pregnant woman's choice to continue her pregnancy to term. According to Sopinka and Major, "When a woman chooses to carry a fetus to term, she must accept some responsibility for its well-being and the state has an interest in trying to ensure the child's health" (emphasis added). ${ }^{154}$ In justifying interventions that would violate a pregnant woman's liberty, the dissenting judges relied again on the pregnant women's "choice": such "interference is always subject to the mother's right to end it by deciding to have an abortion."155 Through the dissenting judgment in this case we can clearly see the tension playing out between choice/responsibility and autonomy. This dilemma of choice was almost completely absent from the majority decision. Justice Lamer, writing for the majority, restricted his comments to the rights of pregnant women and only ventured into a discussion of choice in so far as to acknowledge that "recognition of a fetal action against the mother for lifestyle choices would affect women, who might find themselves incarcerated and treated against their will for conduct alleged to harm the fetus. The proposed changes to the law have complex ramifications impossible for a court to fully assess." ${ }^{\text {156 }}$ Thus for

$\begin{array}{ll}153 & \text { Ibid. } \\ 154 & \text { Ibid. } \\ 155 & \text { Ibid. } \\ 156 & \text { Ibid. }\end{array}$


the majority, the issue of choice is used only in reference to the lack of choices pregnant women would have if the court supported confinement.

LEAF, in their intervener's argument to the Supreme Court of Canada, made a clear break from the choice/responsibility construct attached to reproductive autonomy. Instead of falling into a debate over the rights of the pregnant woman versus the rights of the fetus, LEAF was able to avoid the bifurcated subject altogether by refusing to advocate on the basis of choice. Instead, LEAF argued that the confinement of G would mark a radical departure from past legal principals and that, in ordering confinement, the courts would infringe on G's constitutional rights to equality and thus on her equal access to the right to life, liberty, and security of the person. ${ }^{157}$ In arguing for G's right to equality, LEAF was able to keep the choice/ responsibility door closed - at least in terms of their arguments. By arguing that $\mathrm{G}$ was entitled to equal protection of security of the person, the parameters of the debate are shifted away from the question of fetal subjecthood. There is only one subject in LEAF's factum - G. So careful was LEAF in the $G$ factum not to make the issue about choice that the word "choice" was never used in their factum in reference to reproductive freedom.

In many ways, I feel that LEAF's employment of equality in $G$ is radical. It takes the same damning baggage of liberalism that Ruhl cautioned against in relation to choice and turns it around to benefit $G$ under the banner of equality. Instead of unleashing a narrative of responsibility connected to "choice," this equality framework unleashed a narrative of autonomy related to equality.

\footnotetext{
${ }^{157}$ Women's Legal Education and Action Fund, Winnipeg Child and Family Services vs. G.D.S. Factum, Supreme Court of Canada, Court File: 25508, 4.
} 
Unlike in the Falkiner factum, there is a significant effort to avoid describing what a "good mother" or a "good mother-to-be" might act like. Though LEAF placed a heavy emphasis on the social, cultural, and historical context of the oppression of . aboriginal people and aboriginal women and mothers specifically, they did not turn that critique of colonialism and racism into a new definition of appropriate mothering. LEAF discussed the impact of colonization, reservation living, residential schooling, and later the loss of children to welfare agencies as factors that contribute to the maintenance of the stereotype that aboriginal women are bad mothers, ${ }^{158}$ but they did not provide a new definition or description of good mothers.

LEAF did, however, attempt to tackle the myth that First Nations women are bad mothers. By outlining the historical treatment of First Nations women and children, they brought the myth out into the open. Unlike the Falkiner factum, these images are not used to demonstrate how much like non-Aboriginal mothers First Nations women are, but rather to demonstrate that there are different ways to mother, differences that have historically been used against First Nations women.

Though reference to the historical treatment of First Nations women was used to contrast with contemporary understandings of the good mother, no new definition of good mother is presented by the interveners. In some respects, a new definition might appear to be the next logical step in challenging G's confinement, a step that was taken in Falkiner. Yet, it is clear that G's background and addiction problems would have made it very difficult, if not impossible, for LEAF to argue that G fit any definition of good mother. This absence makes the factum stronger. Instead of moving into a debate of G's

\footnotetext{
${ }^{158}$ Women's Legal Education and Action Fund, Winnipeg Child and Family Services vs. G.D.S. Factum, Supreme Court of Canada, Court File: 25508, 5.
} 
parenting skills, the debate remains firmly focused on G's right to equality protection under the law, regardless of G's actual behaviour as a mother/mother-to-be. Here, the $G$ factum demonstrates a clear break from Falkiner in that it did not take this step and in fact was all the stronger because it protected G specifically, as well as, any other women who might not fit into the idealized vision of good mother.

\section{Conclusion}

The Mossop and $G$ factums directly challenge the "Family/Woman of Legal Discourse" by not reinscribing normative gender roles. A key part of this disruption is in understanding that there are various myths at play, and consequently various legal discourses flowing from the myths. Myth challenging is an important part of destabilizing these discourses; however, as Falkiner demonstrates, it is not enough. Myth challenging only breaks its ties with essentialism when it is coupled with the rejection of dominant normative categories. Such rejections can take different forms. In Mossop, the refusal to abstract or universalize claims about the nature of "families" was intentional and obvious. In $\mathrm{G}$, the refusal to define good mothering was much more subtle, perhaps even unintentional. Yet, both factums demonstrate that such rejection is possible and can be an effective challenge to dominant discourses like the "Woman of Legal Discourse." 


\section{Chapter Six}

\section{Moving Beyond The Equality Impasse}

In many ways the last fifteen years of equality strategizing and litigation have brought us to an apparent impasse. Equality has become the major sticking point. Where feminists, like Jhappan, have tried to theorize alternatives like justice, they have come up against the same limitations that inhere in equality. Where equality litigators have tried to move away from set forms, they have found form pushed back upon them in the courts. It would seem that equality may indeed have become a feminist orthodoxy. And yet, I would argue that there are paths out of this way of thinking, paths that do not demand that we throw our equality baby out with the essentializing bathwater.

Certainly equality and essentialism are intertwined. I could just end this thesis here at the impasse we have been working towards for nearly two decades, conceding that equality is inherently and irredeemably essentialist. But I warned you in the beginning that I am (perhaps always will be) an equality hanger-on. As such, I am forced to ask: if we accept the relationship between equality and essentialism as indivisible, can we nonetheless move the equality project forward in ways that do not perpetuate value laden distinctions among women and do not leave behind the most marginalized and most vulnerable women?

Carol Smart's "Woman of Legal Discourse" helps us understand our own participation in the reinscription of dominant liberal paradigms. When we examine an intervention, like the one in Falkiner, we are better able to see the ways in which our 
arguments contribute to the essentialization of women. Smart's "Woman of Legal

Discourse" can help us to identify what we could have changed in the factum to arrive at a more inclusive piece that might avoid the reinscription of the maternal "Woman of Legal Discourse."

\section{Falkiner Revisited}

The Falkiner factum is an example of saying too little when it needed to say more and saying too much when it should have said nothing at all. On one level, the factum made little to no effort to comprehensively shed light on the multiple forms of oppression that women face. These intersecting factors were not explored at all. On another level, the factum described the type of women who access social assistance at great length, citing statistics on age, number of children, and type of domestic relationship. Though these two levels might seem at odds with each other, they in fact work together in the reinscription of a "Woman of Legal Discourse."

In an effort to make the claim that single mothers are an analogous group entitled to protection under the Charter, the interveners felt it necessary to describe/define that group. Where statistics could be used to aid in the construction of a cohesive "type," LEAF drew upon them. Where difference became a liability to the construction of the single mother, LEAF played them down. In many ways, the interveners were building their own "Woman of Legal Discourse."

One could argue that LEAF's "Woman of Legal Discourse" challenged the "Woman of Legal Discourse" who underpinned the social assistance definition of spouse. 
Perhaps, but as discussed in Chapters Four and Five, the new "Woman of Legal

Discourse" left many women behind. In addition, to draw on Snider, we gave up control of our "Women of Legal Discourse" as soon as we presented her to the courts.

This dilemma brings us back to one of my original questions: "Is it better to build a more robust and comprehensive 'Woman of Legal Discourse' than say nothing at all?" Did we not attempt to do just this in the Falkiner factum? But since we can never control the "Women of Legal Discourses" that we produce or how our contributions will be used, or against whom they will be used, it is critical that we challenge the tendency in feminist legal theory to describe ourselves as good so that the courts will side with us.

Interventions, such as those in Mossop and $G$, demonstrate the importance of refusing to define or redefine a social category. Instead of focusing their energy on creating a more inclusive "Woman of Legal Discourse," the interveners in Falkiner could have refused to define single mothers. As in Mossop and $G$, equality could still have been the key focal point, but the focus could have been on the oppression of single mothers on welfare. Or we could have critiqued the stereotypes connected with single mothers on welfare without reinscribing the essentialisation that a "type" of single mother exists.

This absence of description is an active form of resistance. Rather than "saying nothing at all," the refusal to reinscribe social roles such as family or good mother would serve a counter-hegemonic function by destabilizing the myths that make up the Woman of Legal Discourse and the discriminatory attempts to deny them social assistance based upon ascribed marital status. 


\section{Equality Today}

Equality today is under attack. Where we have won victories in the psychological battle to have equality normalized as a fundamental right, our gains are being clawed back on the economic front. Where decisions against equal treatment (for example, Bliss and Lavell $^{159}$ ) were once rationalized on the basis of women's innate difference from men, today, rulings against equality are legitimized in financial terms through government's inability (read - unwillingness) to pay. ${ }^{160}$

In a time of cutbacks and government belt tightening, the rationale behind rules like the "Spouse in the House" has as much to do with how much a government is willing to spend as it has with how marginalized a group is within society. In fact, the one feeds off the other. Who gets cut is decided by who is the most vulnerable. Today's "Woman of Legal Discourse" is an economic convenience for governments, legitimizing lack of government funding. This makes our interventions even more challenging, because we are ultimately not only trying to change minds, but also attempting to open purse strings.

\section{The Way Forward}

The orthodoxy that we fall into with equality is the tendency to positively stereotype the women we represent in order to achieve victories in the courtroom. We have the power to challenge these stereotypes, not only by providing better, more robust ones, but by rejecting them altogether. Instead of arguing that we are not something by presenting a different something that we are, we can argue that we are not like the "Women of Legal Discourse" and that there is an endless set of possibilities of the

159 Attorney General of Canada v. Lavell; Isaac v. Bedard [1974] S.C.R. 1349; Bliss v. Canada (Attorney General) [1979] 1 S.C.R. 183

160 See for example, Newfoundland (Treasury Board) v. N.A.P.E., [2004] 3 S.C.R. 381 
somethings that we are or can be. We can break out of the impasse in equality strategizing by shifting the terrain of the debate away from typecasting.

Certainly, there will be cases where the clearest path is to present an alternative legal discourse that benefits our client. Mossop is an excellent example of an "easy" case to make. The interveners could have made the claim that Mossop and his partner were "just like" heterosexual couples. While this might have been a strong equality claim, it would simultaneously place other non-traditional couples at risk by not problemetizing the norm of the family. Instead, the interveners refused to reinscribe this category and thus opened up the debate by offering a world of possibilities of and for different families.

On the opposite extreme, the lessons we can draw from $G$ are very similar. Had the applicant been any other, the interveners might have used the "good girl" argument to avoid confinement. But, the circumstances around G's addiction and her past would make such an argument untenable. Yet, an argument for G's right to autonomy and security was available, an argument that came in the form of equality. In this most difficult of cases, equality was most likely the one argument that protected $\mathrm{G}$ from confinement while not exposing her (or others) to moral valuations (at least not value judgments promoted by the intervener's factum).

Equality analysis is not as limited as we have portrayed it to be. The boundaries of equality are no more impermeable than the boundaries of family, and at the same time they are much more flexible than the "good girl" stereotypes that we find ourselves invoking. I will be the first to stand up and admit that equality will not always be the answer. Sometimes we might even need to shift the focus away from equality to another 
legal right that would be less constraining in the circumstances of the specific challenge being made. But such decisions can and should be made with an understanding of equality's potential. The language of equality can be shifted and adjusted to address the inequality at issue. There is room to refuse to participate in placing boundaries on these legal discourses, thus opening these categories up for discussion and broadening the debate. 


\section{Bibliography}

Appiah, Kwane Anthony, "Racisms" in D.T. Goldberg, ed., Anatomy of Racism. Minneapolis: University of Minnesota Press, 1990, 3-17.

Bottomley, Anne, "Shock To Thought: An Encounter (Of A Third Kind) With Legal Feminism," Feminist Legal Studies, 12, no.1,(2004):29-65.

Brodsky, Gwen and Shelagh Day, Canadian Charter Equality Rights For Women: One Step Forward or Two Steps Back? Ottawa: Canadian Advisory Council on the Status of Women, 1989.

Buckley, Melina, Transforming Women's Futures: A Guide to Equality Rights Theory and Action. Vancouver: West Coast Women's Legal Education and Action Fund, 2001.

Canadian Advisory Council on the Status of Women, Women and Legal Action:

Precedents, Resources and Strategies for the Future. Ottawa: Status of Women, 1984.

Canadian Civil Liberties Association, "Spouse in the House," Accessed July 2006, $<$ http://www.ccla.org/privacy/spouse.html $>$

Canadian Statistical Assessment Services, Welfare By the Numbers. Ottawa: Canadian Statistical Assessment Services, 2002.

Chunn, Dorothy E. and Lacombe, Dany, Law as a Gendering Practice. Don Mills:

Oxford University Press, 2000.

Cooper, Davina, "Like Counting Stars: Re-Structuring Equality \& the Socio-Legal Space of SameSex Marriage," in R. Wintemute and M. Andenaes, eds., Legal Recognition of Same-Sex Partnerships: A Study of National, European and International Law. Portland: Hart, 2001, 75-96.

Danius, Sara and Stefan Jonsson, "An Interview With Gayatri Chakravorty Spivak," Boundary 2, 20, no.2, (1993): 24-50.

Freeman, Jody, "Defining Family in Mossop v. DSS: The Challenge of Anti-Essentialism and Interactive Discrimination for Human Rights Litigation," University of Toronto Law Journal Press, 44, no.1,(1994): 41-96.

Gotell, Lise, "LEAF's Changing Approach to Charter Equality," in Radha Jhappan, ed., Women's Legal Strategies in Canada. Toronto: University of Toronto, 2002, 135-174. 
Hekman, Susan, "Truth and Method: Feminist Standpoint Theory Revisited," Signs: Journal of Women in Culture and Society, 22, no.21,(1997): 392-398.

Hillyard Little, Margaret Jane, No Car, No Radio, No Liquor Permit: The Moral Regulation of Single Mothers in Ontario, 1920 - 1997. Toronto: Oxford University Press, 1998.

Jhappan, Radha, 'The Equality Pit or the Rehabilitation of Justice,'in Radha Jhappan, ed., Women's Legal Strategies in Canada. Toronto: University of Toronto, 2002, 175-234.

Kline, Marlee, "Race, Racism and Feminist Legal Theory," Harvard Women's Law Journal, 12 (1989): 115-150.

Lorde, Audre, Sister Outsider: Essays and Speeches. Berkley California: Crossing Press Feminist Series, 1984.

Manfredi, Christopher, Feminist Activism In The Supreme Court: Legal Mobilization and the Women's Legal Education and Action Fund. Vancouver: University of British Columbia Press, 2004.

Minow, Martha, Making All The Difference: Inclusion, Exclusion, And American Law. Ithaca: Cornell University Press, 1990.

Morton F.L. and Allen, Avril, "Feminists and the Courts: Measuring Success in Interest Group Litigation in Canada," Canadian Journal of Political Science, 34, (2001): 55-84.

Morton, F.L. and Rainer Knopff, The Charter Revolution and The Court Party. Peterborough: Broadview Press, 2000.

Naffine, Ngaire, “In Praise of Legal Feminism," Legal Studies, 22, no.1, (2002): 71-101.

Naffine, Ngaire, "Shocking Thoughts: A Reply To Anne Bottomley," Feminist Legal Studies, 12 ,(2004): 175-180.

National Action Committee on the Status of Women, "Herstory," Accessed August 2006, $<$ http://www.nac-cca.ca/about/his e.ht $>$

National Council of Welfare, Profiles of Welfare: Myths and Realities. Ottawa: Ministry of Public Works and Services Canada, 1998.

Phillips, Susan D., "Meaning and Structure in Social Movements: Mapping the Network of National Canadian Women's Organizations," Canadian Journal of Political Science, 24, no.4, (1991): 755-782. 
Razack, Sherene, Canadian Feminism and the Law: The Women's Legal Education and Action Fund and the Pursuit of Equality. Toronto: Second Story Press, Feminist Publishers, 1991.

R.E.A.L. Women, “Official Website,” Accessed February 2007, $<$ hittp://www.realwomenca.com/about.htm $>$

Ruhl, Lealle, "Disarticulating Liberal Subjectivities: Abortion and Fetal Protection," Feminist Studies, 28, no.1,(2002): 37-60.

Salih, Sara, Judith Butler: Routledge Critical Thinkers. London: Routledge, 2002.

Smart, Carol, "The Woman of Legal Discourse," in Carol Smart, Law, Crime and Sexuality: Essays in Feminism. London: Sage, 1995, 186-199.

Snider, Laureen, "Making Change in Neo-Liberal Times," in Gillian Balfour and Elizabeth Comack, eds., Criminalizing Women: Gender and (In)Justice in Neo-Liberal Times. Halifax: Fernwood Publishing, 2006, 323-342.

Spelman, Elizabeth, "Gender \& Race: The Ampersand Problem in Feminist Thought," in K.K. Bhavnani, ed. Feminism and 'Race'. Ottawa: Ottawa University Press, 2001,74-88.

Stone, Alison,"Essentialism and Anti-Essentialism in Feminist Philosophy," Journal of Moral Philosophy, 1, no.1, (2004): 135-153.

Strong-Boag, Veronica, "Ever a Crusader: Nellie McClung," in Veronica Strong-Boag and Anita Clair Fellman, eds., Rethinking Canada: The Promise of Women's History, $3^{\text {rd }}$ ed. Don Mills: Oxford University Press, 1997, 271-284.

Women's Legal Education and Action Fund, "About LEAF Foundation," Accessed July 2006, <http://www.leaf.ca/foundation.html>

Young, Iris Marion, "Gender as Seriality: Thinking About Women as a Social Collectivity," Signs, 19,(1994): 713-738. 


\section{Cases Cited}

Attorney General of Canada v. Lavell; Isaac v. Bedard, [1974] S.C.R. 1349

Bliss v. Canada (Attorney General), [1979] 1 S.C.R. 183

British Columbia (Public Service Employee Relations Commission) v. British Columbia Government Service Employees' Union, [1999] 3 S.C.R. 3, 1999 SCC 48

R. v. Darrach, [2000] 2 S.C.R. 443

R. v. Ewanchuk, [1999] 1 S.C.R. 330

Falkiner v. Ontario (Ministry of Community and Social Services)(2002), 59 O.R. (3d) 481 (C.A.).

M. v. H., [1999] 2 S.C.R. 3

Mossop v. Canada (Attorney General), [1993] 1 S.C.R. 554

Murdoch v. Murdoch, [1975] 1 S.C.R. 423

Newfoundland (Treasury Board) v. N.A.P.E., [2004] 3 S.C.R. 381

Reference re Same-Sex Marriage, [2004] 3 S.C.R. 698

R. v. Rehberg [1993], 127 N.S.R. (2d) 331 (N.S.S.C.)

R. v. Seaboyer; R. v. Gayme, [1991] 2 S.C.R. 577

Schatcher v. Canada, [1992] 2 S.C.R. 679

Winnipeg Child and Family Services (Northwest Area) v. G. (DF), [1997] 3 S.C.R. 925 